\title{
O PRINCÍPIO DA ISONOMIA (IGUALDADE JURÍDICA)*
}

\author{
PAULO PERETTI TORELLY ${ }^{* *}$
}

\begin{abstract}
RESUMO: O artigo contextualiza o princípio da isonomia nos dias de hoje e no curso da história, em termos legislativos, doutrinários e jurisprudenciais, para evidenciar a sua atualidade na preservação dos direitos fundamentais, identificando o mesmo como uma viga mestra da ordem jurídica na vedação do arbítrio.

PALAVRAS-CHAVE: Isonomia, Igualdade, Vedação do Arbítrio.

ABSTRACT: This article is about the principle of equality nowadays and throughout history, in the legislative acts, doctrinal works and court jurisprudence, demonstrating its relevancy today in the support of fundamental rights, and recognizing it as the cornerstone of legal order in the prohibition of discretion.

KEYWORDS: Equity, Equality, Prohibition of Discretion.
\end{abstract}

SUMÁRIO: 1. A Marcha e a Contramarcha da Igualdade; 2. Justiça Formal e Justiça Material (preceitos constitucionais definidores); 3. Isonomia e fatores jurídicos de discriminação; 4. Igualdade e os fatores sexo, raça, credo religioso; 5 . A Regra de Justiça e a Imparcialidade: Isonomia e Poder Judiciário; 6. A Vedação do Arbítrio; 7. Referências.

SUMMARY: 1. Equality's March and Countermarch; 2. Formal and Substantial Justice (defining constitutional precepts); 3. Isonomy and Discretionary Legal Factors; 4. Equality and the gender, race and religious belief factors; 5 . The Justice Rule and the Impartiality: Isonomy and the Judicial Power; 6. The forbidance of arbitrarity; 7. References.

\section{A MARCHA E A CONTRAMARCHA DA IGUALDADE}

A idéia de igualdade enquanto ideal de justiça perseguido pela humanidade ${ }^{1,2}$

* O presente artigo corresponde ao Capítulo 1 do livro “A substancial inconstitucionalidade da regra da
reeleição: Isonomia e República no Direito Constitucional e na Teoria da Constituição”, a ser lançado por
Sergio Fabris Editor.
${ }^{* *}$ Advogado, graduado pela Universidade Federal do Rio Grande do Sul em 1988; Especialista em Direito
Processual Civil (PUC/RS); Mestre em Direito do Estado (PUC/RS); Doutorando em Direito do Estado
(USP); Procurador do Estado desde abril de 1994; ex-secretário-geral adjunto da OAB/RS em 1998 e
Procurador-Geral do Estado do Rio Grande do Sul no período 1999-2002.
${ }^{1}$ ARISTÓTELES. A Política. Tradução de Nestor Silveira Chaves. Bauru, SP: Edipro, 1995, Livro Terceiro,
Cap. XI, § 2, p. 121: “A igualdade na alimentação e no vestuário, quando as condições e as estaturas
diferem, são prejudiciais ao corpo. O mesmo acontece em relação aos direitos: a desigualdade ao lado da
igualdade é uma falta igualmente prejudicial.”
${ }^{2}$ PONTES DE MIRANDA, Francisco Cavalcanti. Democracia, liberdade, igualdade: os três caminhos. 2. ed.
São Paulo: Saraiva, 1979, p. 459: “A igualdade primeira é a do ser humano. Segundo esse princípio, todos 
e fator de legitimação dos sistemas políticos e jurídicos ${ }^{3}$ segue sendo, com todos os seus desdobramentos, o cerne das garantias constitucionais inerentes ao Estado de Direito em um regime democrático e republicano. ${ }^{4}$ Cumpre, portanto, fazer uma breve reflexão acerca da idéia de igualdade no direito e de seus desdobramentos na realidade contemporânea.

"O ponto nevrálgico da história é o problema da igualdade”, 5 asseverou Pontes de Miranda em seu livro Democracia, liberdade, igualdade, em que, na acurada análise de Dante Limongi, identifica-se que "nas poucas vezes em que Pontes admite a presença de valores próprios do direito natural, que reconhece sob a forma de ideal de justiça, a concessão que faz é ao jusnaturalismo escolástico, não ao contratualista”, 6 o que se evidencia ainda mais nesta passagem da obra do singular jurista brasileiro:

"Todas as frases, com que se tenta traduzir o que ocorre nos dias de agora (simples continuação da civilização greco-romana), reconhecem que é a 'maior igualdade' que está em causa. 'Homem comum', 'libertação dos povos', 'melhor estalão de vida’, 'poder aquisitivo das massas’, tudo isto são rifões verbais que correspondem a sentimento e convicção dos homens, ainda quando se preparam, por todos os meios, para adiar ou para evitar a corrente que eles sentem ou percebem.",

nascem iguais em inteligência necessária à vida de relação, em instintos, em aptidão para o bem e para o mal, se bem que haja entre os indivíduos diferenças decorrentes de condições físicas e psíquicas.”

${ }^{3}$ DWORKIN, Ronald. A virtude soberana: a teoria e a prática da igualdade. Tradução de Jussara Simões. São Paulo: Martins Fontes, 2005, p. IX-X: “A consideração igualitária é a virtude soberana da comunidade política - sem ela o governo não passa de tirania - e, quando as riquezas da nação são distribuídas de maneira muito desigual, como o são as riquezas de nações muito prósperas, então sua igual consideração é suspeita, pois a distribuição das riquezas é produto de uma ordem jurídica: a riqueza do cidadão depende muito das leis promulgadas em sua comunidade - não só as leis que governam a propriedade, o roubo, os contratos e os delitos, mas suas leis de Previdência Social, fiscais, de direitos políticos, de regulamentação ambiental e de praticamente tudo o mais.”

${ }^{4}$ BOBBIO, Norberto. Igualdade e liberdade. Tradução de Carlos Nelson Coutinho. 2. ed. Rio de Janeiro: Ediouro, 1997a, p. 8: "Liberdade e igualdade são valores que servem de fundamento à democracia. Entre as muitas definições possíveis de democracia, uma delas - a que leva em conta não só as regras do jogo, mas também os princípios inspiradores - é a definição segundo a qual a democracia é não tanto uma sociedade de livres e iguais (porque, como disse, tal sociedade é apenas um ideal-limite), mas uma sociedade regulada de tal modo que os indivíduos que a compõem são mais livres e iguais do que em qualquer outra forma de convivência.”

${ }^{5}$ PONTES MIRANDA, 1979, p. 517.

${ }^{6}$ LIMONGI, Dante Braz. O projeto político de Pontes de Miranda: Estado e democracia na obra de Pontes de Miranda. Rio de Janeiro: Renovar, 1998, p. 228.

${ }^{7}$ PONTES DE MIRANDA, 1979, p. 517. No mesmo sentido Pontes de Miranda também atesta - em seu Comentários à Constituição de 1946. 4. ed. Rio de Janeiro: Editor Borsoi, 1963, t. IV, p. 145 - a distinção entre a proteção dos direitos fundamentais pelo Estado e a existência prévia destes em face do direito das gentes: "Direitos fundamentais valem perante o Estado, e não pelo acidente da regra constitucional. São concepções estatais dentro das raias que aos Estados permite o direito das gentes. Tais concepções não lhes alteram a essência: são concepções da proteção e não da existência de tais direitos. A sua essência, a sua supra-estatalidade (Uberstaatlichkeit) é inorganizável pelo Estado; o que é organizável, como demonstrou a ciência de trinta anos atrás, é a proteção jurídica (K. Woltzendorff, Staatsrecht und Naturrecht, Berlim, 1916). Mas, para nós, isso não quer dizer que, evolucionando, o direito das gentes não possa chegar à organização dos direitos fundamentais. Os conjuntos de direitos fundamentais olham, de frente, o Estado; constituem (R. Thoma, Festgabe, 187) 'estações no eterno processo the Man versus the State, em ondas que vão e vem'. A técnica das declarações é que muda. Se procedem do direito natural, ou não, é problema que não se deve levantar 
E ainda hoje é na perspectiva da igualdade que se colocam diversas indagações, decorrentes do que se diagnostica como sendo uma verdadeira crise da racionalidade que torna ainda mais sensível o que se conhece como razões de Estado, ${ }^{8}$ pois a humanidade vivencia um estágio no qual é especialmente necessário refletir sobre o poder e seus fundamentos - força, astúcia, pacto,vontade divina, síntese histórica, etc. - para definir ou, no mínimo, saber se o Príncipe está acima da força coercitiva das leis e se a legalidade é ou não expressão da legitimidade, ${ }^{9}$ presente no conjunto da realidade normativa enquanto reflexo da totalidade das interações sociais. Mais do que isso, é verdadeiramente necessário, nas palavras de João Hansen, indagar: “A política prescinde da moral? E, se tudo se subordina à vontade absoluta de Um, o que é a vontade, o que é a liberdade, o que são os direitos dos súditos?”10

Tais indagações, portanto, revestem-se de grande atualidade diante da constatação de Ronald Dworkin:

“A igualdade é espécie ameaçada de extinção entre os ideais políticos. Até poucas décadas atrás, qualquer político que se declarasse liberal, ou mesmo de centro, acreditava que a verdadeira sociedade igualitária era, pelo menos, um ideal utópico. Atualmente, porém, até os políticos que se declaram de centro-esquerda rejeitam o próprio ideal da igualdade. ${ }^{11,}$

Por outro lado, no que pese a ameaça de tal paradoxo, é importante destacar que, como bem apanha Sergio Rouanet, o "universalismo ilustrado gerou efeitos políticos importantes, como a condenação de qualquer forma de racismo, de colonialismo, de sexismo", 12 de tal modo que, mesmo diante da constatação de que "os autores que pregavam a igualdade natural raramente eram apóstolos da implantação efetiva, na vida social, da igualdade econômica”, ${ }^{13}$ é de se reconhecer, sem qualquer vacilação, que:

no direito constitucional. Antes, no direito das gentes, já se pôs. Sejam direitos naturais, ou não sejam, já no direito constitucional se erguem diante do Estado, pela proeminência do direito das gentes, que - não obstante a sua imperfeição - é o direito humano no mais alto grau”. É importante referir que o sentido de objetivação dos fatos sociais pelo direito, presente na obra de Pontes de Miranda, guarda identidade com o positivismo cientificista, o que se aproxima mais do direito natural escolástico do que do direito natural de matriz contratualista ou mesmo do direito positivo em sua acepção normativista, o que é bem apanhado por Miguel Reale ao observar que tal expressão do "naturalismo jurídico” (Ibidem infra) na obra do célebre jurista das Alagoas trabalha com a concepção de que “o fato jurídico é um fato da mesma natureza e estrutura dos chamados fatos físico-naturais” (REALE, Miguel. Filosofia do Direito. 9. ed. São Paulo: Saraiva, 1982, p. 182). Nesse sentido Pontes de Miranda observa, acerca da "naturalidade do fenômeno jurídico”, que: “À vida humana não é essencial o Estado; o que é imprescindível às organizações humanas, às sociedades, é o ritmo, a ordem. Trabalho e harmonia são os princípios mais gerais da evolução social.” (PONTES DE MIRANDA, Francisco Cavalcanti. Sistema de ciência positiva do direito. 2. ed. Rio de Janeiro: Borsoi, 1972, t. I, p. 75).

${ }^{8}$ GARCÍA, Eusebio Fernández. Entre la razón de Estado y el Estado de Derecho: la racionalidad política. Madrid: Dykinson, 1997, p. 29: "la razón de Estado se opone al império de la ley y al sometimiento a ella de gobernantes y gobernados, bases imprescindibles del Estado de Derecho.”

${ }^{9}$ HANSEN, João Adolfo. Razão de Estado. NOVAES, Adauto (Org.). A crise da razão. São Paulo: Companhia das Letras; Brasília, DF: Ministério da Cultura; Rio de Janeiro: Fundação Nacional de Arte, 1996, p. 135.

${ }^{10}$ Ibid.

${ }^{11}$ DWORKIN, 2005, p. IX.

${ }^{12}$ ROUANET, Sergio Paulo. Mal-estar na modernidade: ensaios. São Paulo: Companhia das Letras, 1993, p. 15.

${ }^{13}$ Ibid., p. 19. O autor ainda lembra: “Deplorar o contraste entre os palácios e as choupanas é um lugar-comum 
“A força libertadora desse universalismo foi real. Reafirmando a igualdade de todos os seres humanos diante da razão, ela transpôs para o terreno secular da luta filosófica e política a idéia religiosa de que todos são filhos de Deus e iguais diante do Criador, o que teve conseqüências explosivas. ${ }^{14,}$

Aqui, entretanto, mais uma vez se constata a acuidade de Pontes de Miranda diante do difícil processo de assimilação da autonomia dos “Direitos do Homem” em face do Estado, o que não impediu a afirmação histórica - ainda que penosa e muitas vezes contraditória - desses direitos na ordem interna e, particularmente, na ordem internacional, pois observa que:

“As tendências fascistas e o terrorismo extremista querem que todos êles sejam estatais, sòmente direitos do cidadão, e nunca pré- ou supra-estatais. Mas já é tarde para se proceder a êsse desvio da civilização, não só ocidental como mundial. Por outro lado, enquanto os Estados fascista, nacionalista e soviético põem o dedo na chaga: a "liberdade" econômica, falsa liberdade com que se escraviza o grande número, sem outro critério de seleção que o bom êxito pecuniário, os Estados liberais e democráticos, que defendem, com razão, algumas aquisições do homem, aquisições que fazem parte da sua dignidade e do seu valor, erram em ligar a sorte de tais aquisições à defesa do liberalismo manchesteriano, teoria anárquica da economia - anarquismo da direita, mas, de qualquer modo, anarquismo. Desgraçadamente, há pior do que êsse anarquismo: a intervenção acientífica, sob a pressão de intêresse dos monocratas e dos oligocratas, civis e militares. ${ }^{15}$,

“A democracia precisa de liberdade”, ${ }^{16}$ também asseverou Pontes de Miranda, atestando que "o socialismo teria de reconhecer-se como o lado de um triângulo: sem ele o triângulo não seria; mas, sem democracia ou sem liberdade, não no seria tampouco", 17 por isso sustentava que "a liberdade inglesa, a democracia americana e a igualdade russa são os pontos avançados dos três caminhos”, ${ }^{18}$ restando patente o

das Luzes. Por isso, o ideal de Rousseau era uma ordem social em que todos pudessem satisfazer suas necessidades de alimentação, moradia e vestuário, uma ordem de igualdade relativa em que 'ninguém fosse tão pobre que precisasse vender-se nem tão rico que pudesse comprar os outros’” (Id. Ibid., p. 18).

${ }^{14}$ Ibid., p. 15.

${ }^{15}$ PONTES DE MIRANDA, Francisco Cavalcanti. Comentários à Constituição de 1967/69. 3. ed. Rio de Janeiro: Forense, 1987, t. IV, pp. 632-633.

${ }^{16}$ Id., 1979, p. 403.

${ }^{17}$ Ibid., p. 402.

${ }^{18}$ Ibid., p. VII. É particularmente instigante a seguinte passagem de Pontes de Miranda acerca da obra de Hegel: "Dentro de Hegel, lutavam, em paradoxo trágico, a sua admiração pela Prússia e a sua simpatia pela Revolução francesa: a realização do sufrágio universal pela Grã-Bretanha deu oportunidade a que mostrasse a contradição (o modus vivendi endopsíquico!) entre o Hegel ledor de J.J. Rousseau e de Schiller e o Hegel que admirava a Prússia frederiquiana de Stein e as reformas feitas pelos príncipes alemães, auctoribus illis ipsis. O Hegel moço servia às esquerdas (1825-1848); o Hegel velho às direitas. O bill ingles do sufrágio universal mexia-lhe os nervos: um Hegel tinha de ser riscado, dentro dele. Esse estado de espírito quanto à Inglaterra ainda hoje é encontrado em mais de cinqüenta por cento dos dirigentes reacionários dos outros países: o medo de que a Grã-Bretanha da liberdade de pensamento encontre a fórmula entre a democracia dos Estados Unidos da América e a igualdade soviética” (Ibid., pp. 402-403). 
reconhecimento da importância da afirmação permanente de uma maior igualdade substantiva. ${ }^{19,20}$

Mas o valor de tais registros da reflexão do maior jurista brasileiro do século passado se dá diante do já referido paradoxo que hoje a humanidade vivencia em face da freqüente negação dos valores igualitários apontada por Dworkin, ${ }^{21}$ sendo emblemática a seguinte síntese de Sergio Rouanet:

“O cosmopolitismo da Ilustração cedeu lugar aos nacionalismos mais estridentes, em parte justificados pela doutrina liberal da autodeterminação dos povos. No fundo o internacionalismo remanescente se limitou à convicção de que a expansão do capital exigia a derrubada das barreiras nacionais - de preferência nos países subdesenvolvidos. O pacifismo ilustrado foi substituído pela prática da Guerra e até por sua apologia, como aplicação da doutrina darwinista da luta pela existência e da seleção natural. O imperialismo se generalizou, contrariando o anticolonialismo da Ilustração. ${ }^{22,}$

É nesta quadra que calha a precisa distinção apontada por Norberto Bobbio entre a igualdade enquanto princípio do Estado liberal e enquanto princípio do Estado social, dado que, naquele se limitou à idéia de "igualdade perante a lei”, 23 enquanto neste último se materializou na idéia de "igualdade de oportunidades", ${ }^{24}$ pelo que refletem, na realidade, a aplicação da regra de justiça. E é em Aristóteles (383-322 a.C.) que se identifica a idéia de regra de justiça $a^{25,26}$ - se as pessoas não forem iguais, elas não

\footnotetext{
${ }^{19}$ Id., 1987, p. 667: “Quando empregamos 'maior igualdade', aludimos, portanto, ao caminho para se chegar à igualdade. O conceito perde, então, aquêle conteúdo ao mesmo tempo aritmético e místico, que adquiriu em certos revolucionários. Por algum tempo teve isso o efeito sádico de fazer a classes favorecidas sentirem como se lhes estivessem a cortar méritos e qualidades; e ultrapassasse o sentido mesmo da lei sociológica. (No sentido da evolução, desde que o bem-estar material e o valor de cada um crescem, quanto à educação, à saúde e à atuação social, o dia de hoje é superior ao de ontem.)”.

${ }^{20}$ Id., 1979, p. 600: “A maior igualdade fez a Rússia sair da ruína e chegar a quase um terço da produção de todo o mundo. Falta-lhe a liberdade”. Acerca dessa passagem, cabe referir o registro de Dante Braz Limongi, 1998, p. 240: "Pontes foi signatário de um manifesto de apoio à Revolução de 1917, na Rússia, mas não desejava copiá-la, entendendo-a como resultado das condições específicas daquele país. Lá, devido às resistências, tinha lugar a socialização catastrófica e ele desejava a socialização progressiva, que distribuiria a propriedade aglomerada nas mãos de alguns.”

${ }^{21}$ Vide citação da nota 11.

${ }^{22}$ ROUANET, 1993, p. 20. É, ainda, significativa a referência de Sergio Rouanet aos limites da racionalidade iluminista quando observa que: “O que está se verificando cada vez mais, como efeito, é uma regressão ao estado de coisas denunciado pelos enciclopedistas. $\mathrm{O}$ que eles ingenuamente chamavam superstição volta em triunfo, muitas vezes aureolado com o prestígio da ciência. O presidente de uma superpotência chama outra superpotência de 'império do mal' e ameaça o mundo com o Armageddon bíblico.” (Ibid., 1993, p. 23).

${ }^{23}$ BOBBIO, 1997a, p. 30.

${ }^{24}$ Ibid., p. 30

${ }^{25}$ Ibid., p. 20.

${ }^{26}$ DEL VECHIO, Giorgio. Lições de filosofia do direito. Tradução de António José Brandão. 5. ed. Coimbra: Armênio Amado, 1979, p. 34. O jusfilósofo italiano identifica na reflexão dos pitagóricos a idéia precursora de igualdade enquanto princípio fundamental de justiça, pois nos diz: “A intuição fundamental de PITÁGORAS é a de que a essência de todas as coisas é o número. Donde: o princípio numérico é princípio das coisas. Este conceito matemático abre caminho a considerações astronómicas, musicais e políticas. Assim, para os pitagóricos, a Justiça é relação aritmética, uma equação ou igualdade. À luz desta concepção, deduzem o
} 
terão uma participação igual nas coisas ${ }^{27}$ - enquanto definidora do referencial que, por sua vez, exige a identificação prévia de "quando duas coisas devem ser consideradas equivalentes e quando duas pessoas devem ser consideradas equiparáveis”, ${ }^{28}$ de tal modo que aquela regra seja uma máxima de justiça erigida nestes termos: tratar os iguais de modo igual e os desiguais de modo desigual. ${ }^{29}$ Nas palavras de Bobbio: "Somente depois que estes critérios foram escolhidos é que a regra de justiça intervém para determinar que sejam tratados do mesmo modo os que se encontram na mesma categoria.” ${ }^{30} \mathrm{O}$ conteúdo da regra de justiça, portanto, é um pressuposto que terá como grande valor a determinação da justiça enquanto "conservação da ordem social” ${ }^{\text {"31 }}$ ou, é possível concluir, seu aprimoramento e evolução diante, v.g., de uma dada ideologia constitucional que preconize a justiça social. ${ }^{32}$ Logo, "varia de sociedade para sociedade a definição de quais devam ser as posições de partida a serem consideradas como iguais, de quais devam ser as condições sociais e materiais que permitam considerar os concorrentes iguais". 33

Nesta quadra se destaca a análise de Avelãs Nunes acerca das conseqüências da hegemonia das políticas monetaristas diante do pensamento (neo)keynesiano, porquanto comprometem diretamente a eficácia dos direitos fundamentais com uma agenda ideológica pautada pela adesão passiva ao modelo de globalização econômica da atual fase do capitalismo mundial, dado que sustentam que "a inflação é sempre e em qualquer lugar um fenômeno exclusivamente monetário (resultante de um aumento da quantidade de moeda em circulação em maior medida que o aumento da produção)" 34 e, portanto, "procuram combater a inflação essencialmente com base na redução do crescimento da oferta de moeda”35, razão pela qual:

"Esta política anti-inflacionista opera através da contracção da actividade económica e do aumento do desemprego, esperando os seus defensores que daqui resulte uma redução dos salários reais capaz de assegurar às empresas uma taxa de lucro suficientemente elevada para estimular o aumento dos investimentos privados e o relançamento posterior da economia, com o consequente aumento do volume

conceito de retribuição, de troca, de correspondência entre o facto e o tratamento adequado dele. Encontra-se nesta concepção - a qual se aplica igualmente à pena - o germe da futura doutrina aristotélica da Justiça.” (Id. Ibid., p. 34).

${ }^{27}$ ARISTÓTELES. Ética a Nicômaco. São Paulo: Nova Cultura, 1996, v. 1, nº 3, p. 198.

${ }^{28}$ BOBBIO, 1997a, p. 20.

${ }^{29}$ BOBBIO, 1997a, p. 20.

${ }^{30}$ Ibid., pp. 20-21.

${ }^{31}$ Ibid., pp. 20.

${ }^{32}$ Ibid., p. 21: "Desse ponto de vista, a relação entre a justiça retributiva e atributiva, por um lado, e a regra de justiça, por outro, pode ser concretizada do seguinte modo: a primeira é constitutiva ou reconstitutiva da igualdade social; a segunda tende a mantê-la segundo os modos e formas em que foi estabelecida.”

${ }^{33}$ Ibid., p. 31.

${ }^{34}$ NUNES, António José Avelãs. Neoliberalismo e Direitos Humanos. Rio de Janeiro: Renovar, 2003, pp. 15-16. É de se consultar, do mesmo autor e acerca da particularidade brasileira, sua tese de doutoramento, desenvolvida na Universidade de Coimbra e intitulada "Industrialização e desenvolvimento: a economia política do 'modelo brasileiro de desenvolvimento'”. Boletim da Faculdade de Direito de Coimbra (supl.). Coimbra, 1982, $\mathrm{n}^{\circ}$ 24-25.

${ }^{35}$ Ibid., p. 16. 
do emprego. Essencial é que se entregue a economia ao livre jogo das 'leis do mercado', se reduza a intervenção do estado na economia e se anulem os “monopólios sindicais". ${ }^{36, "}$

É, portanto, no pensamento de Isaiah Berlin, caracterizado pela relativização da supremacia do legado iluminista e pela negação do monismo, dado que entende que a realidade é governada por diversos princípios elementares, que encontramos a mais adequada identificação da idéia de igualdade nos tempos atuais. E tal se dá diante de uma realidade em que a própria regra de justiça é cada vez mais difícil de ser concretizada, porquanto se sua essência aristotélica consiste, como bem apanhado por Norberto Bobbio, em "tratar os iguais de modo igual e os desiguais de modo desigual”, ${ }^{37}$ há que se resolverem previamente "os critérios para estabelecer quando duas coisas devem ser consideradas equivalentes e quando duas pessoas devem ser consideradas equiparáveis". ${ }^{8}$ Assim, para Isaiah Berlin, "em situações concretas nem toda reivindicação tem igual força - um tanto de liberdade e um mesmo tanto de igualdade", 39 pelo que "devem-se estabelecer prioridades, jamais finais e absolutas", 40 de tal modo que:

“A igualdade pode exigir a restrição da liberdade daqueles que desejam dominar; a liberdade - sem a qual não há escolha e, portanto, nenhuma possibilidade de continuarmos humanos, assim como compreendemos a palavra - pode ter de ser cerceada a fim de abrir espaço para o bem-estar social, para alimentar os famintos, para vestir os nus, para abrigar os sem-teto, para permitir a liberdade dos outros, para tornar possível que a justiça ou a imparcialidade sejam exercidas. ${ }^{41 "}$

Mas, ainda que se concorde plenamente com Isaiah Berlin quando aponta que diante da injustiça “Hegel propõe uma 'sublimação' em algum nível mais elevado”,42 e acaba por negar que a "espontaneidade, uma qualidade humana maravilhosa, não é compatível com a capacidade para o planejamento organizado, para o cálculo sutil do quê, de quando e de onde - do qual o bem estar da sociedade pode depender bastante”, ${ }^{3}$ não há como se prescindir de um parâmetro objetivo. E tal não é contraditório com o processo objetivo de aprimoramento cultural de cada sociedade, o que se sobressai diante do realismo da observação de Norberto Bobbio ao apontar que "liberdade e igualdade são mais normais do que disciplina e hierarquia somente

\footnotetext{
${ }^{36}$ NUNES, 1982, p. 16. O autor identifica, em outra passagem, o papel dos bancos centrais, vale dizer, das estruturas estatais de regulação da moeda e do crédito, neste processo: "Abandonado há muito o padrão-ouro sem qualquer hipótese de recuperação e esgotado o sistema monetário internacional saído de Bretton Woods (1944), a 'irmandade dos bancos centrais' (James Tobin) colocou-se à ortodoxia monetarista, na esperança de encontrar nas suas receitas instrumentos de defesa perante as pressões políticas dos governos, o que favoreceu o processo de 'ascenção do monetarismo'” (Id. Ibid., p. 10).

${ }^{37}$ BOBBIO, 1997a, p. 20.

${ }^{38}$ Ibid.

${ }^{39}$ BERLIN, Isaiah. Estudos sobre a humanidade: uma antologia de ensaios. Tradução de Rosaura Eichenberg. São Paulo: Companhia das Letras, 2002, p. 55.

${ }^{40}$ Ibid., p. 55.

${ }^{41}$ Ibid., p. 51

${ }^{42}$ Ibid.

${ }^{43}$ BERLIN, 2002, p. 51
} 
em sentido normativo, no universo do dever ser”. ${ }^{44}$ É possível, portanto, constatar que Isaiah Berlin também anda no mesmo sentido quando, com a sabedoria que o consagrou como pensador de referência, lembra que "a situação concreta é quase tudo" ${ }^{45}$ e que "devemos decidir no momento da decisão", 46 considerando todos os "fatores relevantes", 47 de tal modo que "os objetivos que procuramos realizar sejam vistos como elementos de um contexto total de vida, que pode ser intensificada ou danificada pelas decisões”. ${ }^{48}$ Assim, o pensador conclui com a seguinte observação:

"Mas, no final, não se trata de uma questão de julgamento puramente subjetivo, mas do que é ditado pelas formas de vida da sociedade a que se pertence, uma sociedade entre outras sociedades, com valores mantidos em comum, estejam ou não em conflito, pela maioria da humanidade ao longo de toda a história registrada. Há, se não valores universais, ao menos um mínimo sem o qual as sociedades não poderiam sobreviver. ${ }^{49}$,

E, dentre esses valores que se universalizam, por certo bem apanhou Pontes de Miranda a primazia da dignidade da pessoa humana ainda ao comentar a Constituição de 1946, visto que, com uma dimensão humanista que não negligencia no rigor teórico, já doutrinava:

“A afirmação e o reconhecimento da dignidade humana, o que se operou por lentas e dolorosas conquistas na história da humanidade, foi o resultado de avanços, ora contínuos, ora esporádicos, nas três dimensões: democracia, liberdade, igualdade. Erraria quem pensasse que se chegou perto da completa realização. A evolução apenas se iniciou para alguns povos; e aqueles mesmos que alcançaram, até hoje, os mais altos graus ainda se acham a meio caminho. A essa caminhada corresponde a aparição de direitos, essenciais à personalidade ou à sua expansão plena, ou à subjetivação e precisão de direitos já existentes. ${ }^{50,}$

Assim, ainda viceja a lição de Pontes de Miranda quando, diante da igualdade enquanto "princípio dos princípios” dotado de efetividade em toda ordem jurídica que aspire a ser justa, com singular acuidade, asseverou:

“A regra jurídica que dissesse “Todos são iguais” seria impotente para igualizar tudo. A cada caso ter-se-ia de procurar o conteúdo de tal regra jurídica, para se ver se, na matéria em discussão, é possível a igualização; mesmo porque, onde os seres humanos são desiguais (A produz $x$ com o seu trabalho; B, por ser inválido, nada produz; C, por lhe não agradar o trabalho, só produz fração de $x$ ), a igualização desigualizaria. O igualitarismo abstrato não presta atenção a que teria, a cada momento, de fazer política “desigualizante”. ${ }^{1}$ ”,

${ }^{44}$ BOBBIO, 1997a, p. 10.

${ }^{45}$ BERLIN, op. cit., p. 56

${ }^{46}$ Ibid.

${ }^{47}$ Ibid.

${ }^{48}$ Ibid.

${ }^{49}$ Ibid.

${ }^{50}$ PONTES DE MIRANDA, Francisco Cavalcanti. Comentários à Constituição de 1946. 4. ed. Rio de Janeiro: Editor Borsoi, 1963, v. 4, p. 238.

${ }^{51}$ Id., 1987, pp. 642-643. 


\section{JUSTIÇA FORMAL E JUSTIÇA MATERIAL (PRECEITOS}

CONSTITUCIONAIS DEFINIDORES)

Estabelecidas as premissas que fundamentam esta pesquisa, cabe distinguir a justiça formal da justiça material, pelo que desde já se faz necessário destacar a diferença entre a igualdade perante a lei - forma específica e historicamente determinada de igualdade de direito ou dos direitos ${ }^{52}$ - e a igualdade nos direitos. Esta última, além de contemplar o direito de ser igual perante a lei previsto na primeira, contempla os direitos fundamentais assegurados constitucionalmente. ${ }^{53}$ É significativa, neste aspecto, a lição de Miguel Carbonell ao observar que:

"Para el pensamiento constitucional el principio de igualdad ha tenido en el pasado, tiene en la actualidad y está llamado a tener en el futuro una importancia capital. Desde el nacimiento mismo del Estado constitucional la igualdad no ha dejado de figurar como uno de los principios vertebradores de dicho modelo de Estado. ${ }^{54,}$

Assim, hoje não há como se contestar que a igualdade nos direitos é mais do que a igualdade perante a lei - exclusão de qualquer discriminação não justificada ${ }^{55}$ -, logo significa "igual gozo, por parte dos cidadãos, de alguns direitos fundamentais constitucionalmente assegurados”. ${ }^{56}$ Tal garantia verifica-se na Declaração de Direitos do Homem e do Cidadão, aprovada pela Assembléia Nacional da França em 1789, ${ }^{57}$ e na Declaração Universal dos Direitos do Homem, aprovada pela Assembléia Geral da Organização das Nações Unidas em 1948, onde naquela já constava que Os homens nascem e permanecem livres e iguais nos direitos, enquanto que nesta última se vislumbra que Todos os homens nascem livres e iguais em dignidade e direitos. ${ }^{58}$

A acuidade da fórmula mais recente fica patente quando se observa que Robert Alexy parte exatamente do conhecimento prático de que não existem duas pessoas ou duas situações humanas entre as quais não se faça presente tanto uma igualdade fática parcial, quanto uma desigualdade fática parcial, para concluir que todos deveriam ser tratados sempre com igualdade ou desigualdade diante da igualdade e da desigualdade fática parcial em algum aspecto, de tal modo que:

${ }^{52}$ BOBBIO, 1997a, p. 29.

${ }^{53}$ Ibid.

${ }^{54}$ CARBONELL, Miguel. La igualdad y los derechos humanos. In: CARBONELL, Miguel. (Comp.). El principio constitucional de igualdad: lecturas de introducción. México: Comisión Nacional de los Derechos Humanos, 2003. p. 9.

${ }^{55}$ BOBBIO, 1997a, p. 29.

${ }^{56}$ Ibid.

57 JACQUES, Paulino. Da igualdade perante a lei: fundamento, conceito e conteúdo. Rio de Janeiro: Forense, 1957, pp. 91-92: “A Declaração dos Direitos do Homem e do Cidadão, de 26.08.1789, que sofreu a influência de MIRABEAU, foi o primeiro estatuto político a ministrar elementos positivos para a conceituação da igualdade jurídica. No art. $1^{\circ}$ rezava: 'Les hommes naissent et demeurent libres et égaux em droits. Les distinctions sociales ne peuvent être fondées que sur l'utilité commune'. A segunda parte do dispositivo dá a medida da primeira, porque afirma não ser absoluta a 'igualdade em direitos', que admite 'distinções sociais', desde que fundadas na 'utilidade comum'. Contanto que seja útil à sociedade, poderá haver distinções entre os indivíduos, sem que isso ofenda a igualdade de direitos. É que esta pressupõe a igualdade de condição. Todos os indivíduos da mesma condição são iguais em direito.”

${ }^{58}$ BOBBIO, 1997a, p. 29. 
“Como no existe ni una igualdad ni una desigualdad en todos los respectos (igualdad/desigaldad fáctica universal) entre las personas y las situaciones personales y como la igualdad (desigualdad) fáctica parcial en algún respecto no basta como condición de aplicación de la fórmula, ésta puede referirse sólo a una cosa: la igualdad y la desigualdad valorativa. ${ }^{59, "}$

Aqui, portanto, faz-se necessário, com esteio na reflexão de Norberto Bobbio, ${ }^{60}$ identificar com precisão a distinção entre igualdade jurídica, igualdade perante a lei e igualdade nos direitos, em que se observam:

“a) Igualdade jurídica: parte da idéia de que todos os membros de uma sociedade são sujeitos de direito, de tal modo que nega, v.g., a sociedade escravista, em que "nem todos os membros são pessoas jurídicas". 61

b) Igualdade perante a lei: é mais ampla que a igualdade jurídica e consiste, conforme já referido, em uma "forma específica e historicamente determinada de igualdade de direito ou dos direitos”, 62 vedando qualquer discriminação injustificada. Nega, portanto, a sociedade de estamentos e pode ser exemplificada no "direito de todos de terem acesso à jurisdição comum, ou aos principais cargos civis e militares, independentemente do nascimento", ${ }^{63}$

c) Igualdade nos direitos (também formulada como dos direitos): âmbito mais amplo que a igualdade perante a lei e que contempla os direitos fundamentais, "tais como os direitos civis e políticos, geralmente proclamados (o que não significa que sejam reconhecidos de fato) em todas as Constituições modernas”. ${ }^{64,}$

Logo, faz-se possível a distinção entre igualdade formal e igualdade material. Usualmente se fala naquela enquanto expressão da igualdade de direito e nesta última enquanto expressão da igualdade de fato, ${ }^{65}$ o que faz da igualdade nos direitos mais do que a vedação da discriminação arbitrária ou mesmo injustificada. ${ }^{66}$ Nesse ensejo é importante referir a reflexão de Alfonso Miguel ao ponderar que se deve considerar um sentido diferente de "formal", pois um determinado modelo pode "ser formal sin ser vacío, en cuanto forma abierta, en la medida en que organice nuestras ideas en una determinada línea, excluyendo al menos ciertas derivaciones y, por tanto, comprometiendo otras”. ${ }^{67}$ Mas, ainda antes, cabe atentar para a distinção que Norberto Bobbio faz entre liberdade e justiça, em que aquela consiste em um "valor supremo do indivíduo

\footnotetext{
${ }^{59}$ ALEXY, Robert. Teoria de los derechos fundamentales. Traducción de Ernesto Garzón Valdés. Madrid: Centro de Estudios Constitucionales, 1997, p. 387.

${ }^{60}$ BOBBIO, 1997a, p. 30.

${ }^{61}$ Ibid., p. 30.

${ }^{62}$ Ibid., p. 29.

63 Ibid.

${ }^{64}$ Ibid.: "a igualdade nos direitos compreende, além do direito de serem considerados iguais perante a lei, todos os direitos fundamentais enumerados numa Constituição”.

${ }^{65}$ Ibid.

${ }^{66}$ Ibid.

${ }^{67}$ MIGUEL, Alfonso Ruiz. Sobre el concepto de igualdad. In: CARBONELL, Miguel. (Comp.). El principio constitucional de igualdad: lecturas de introducción. México: Comisión Nacional de los Derechos Humanos, 2003, p. 59.
} 
em face do todo", ${ }^{68}$ sendo um "bem individual por excelência”69, enquanto a última é um "bem supremo do todo enquanto composto de partes"70, sendo um "bem social por excelência"71, dado que "enquanto a justiça é um ideal, a igualdade é um fato", ${ }^{72}$ razão por que, com precisão, o pensador italiano observa:

“A esfera de aplicação da justiça, ou da igualdade social e politicamente relevante, é a das relações sociais, ou dos indivíduos ou grupos entre si, ou dos indivíduos com o grupo (e vice-versa), segundo a distinção tradicional, que remonta a Aristóteles, entre justiça comutativa (que tem lugar na relação entre as partes) e justiça distributiva (que tem lugar nas relações entre o todo e as partes, ou vice-versa). $^{73,}$

É, entretanto, apenas em parte que se busca na situação objetiva o critério de justiça, no qual a cada um é dado o que é seu (mérito, capacidade, talento, esforço, trabalho, resultado, necessidade, posto), pois a escolha de qual critério incide em cada situação dependerá das "diversas concepções gerais da ordem social”, ${ }^{74}$ sempre pressupondo que já tenham sido equacionadas a escolha e a definição de "quando duas coisas devem ser consideradas equivalentes e quando duas pessoas devem ser consideradas equiparáveis". ${ }^{75}$ Neste particular é emblemática a disputa ideológica que se faz presente no confronto entre o critério do mérito e o da necessidade, pois "a máxima 'a cada um o seu’ não anuncia nenhum critério, mas abrange e tolera, em cada oportunidade concreta, todos eles”. ${ }^{76} \mathrm{Na}$ mesma direção anda Robert Alexy quando identifica a possibilidade de instrumentalização do princípio da isonomia pelo próprio arbítrio, ao observar que o enunciado "Hay que tratar igual a lo igual y desigual a lo desigual no contiene un criterio tal sino que su aplicación lo presupone”, 77 advertindo:

"Si el principio general de igualdad se limitara a una práctica universalista de decisión, el legislador podría llevar a cabo cualquier discriminación sin violarlo, siempre que lo presentara bajo la forma de normas universales, algo que siempre es posible. Bajo esta interpretación, la legislación nacionalsocialista contra los judíos no violaría la fórmula Hay que tratar igual a lo igual y desigual a lo desigual. ${ }^{78,}$

Não por outra razão Alfonso Miguel pondera que "calificar a una relación como relación de igualdad permite poner de manifiesto la relevancia de los aspectos coincidentes entre los términos comparados."79 Logo, na família prepondera o critério

\footnotetext{
${ }^{68}$ BOBBIO, 1997a, p. 16.

${ }^{69}$ Ibid., p. 16.

${ }^{70}$ Ibid., p. 16.

${ }^{71}$ Ibid., p. 16.

${ }^{72}$ Ibid., p. 16.

${ }^{73}$ Ibid., p. 16.

${ }^{74}$ Ibid., p. 19.

${ }^{75}$ Ibid., p. 20.

${ }^{76}$ Ibid., p. 20.

${ }^{77}$ ALEXY, 1997, p. 388.

${ }^{78}$ Ibid., p. 386.

${ }^{79}$ MIGUEL, 2003, p. 46.
} 
da necessidade; na escola, o do mérito; em uma sociedade anônima, a quantia de quotas de propriedade e em uma sociedade leonina, a força, sendo que "a comunidade internacional é, em grande parte, uma sociedade leonina", 80

Confrontando a igualdade e a liberdade, Norberto Bobbio destaca que "a liberdade é uma qualidade ou propriedade da pessoa (não importa se física ou moral)”,81 e "a igualdade é pura e simplesmente um tipo de relação formal", ${ }^{2}$ de tal modo que "a liberdade é a qualidade de um ente, enquanto a igualdade é um modo de estabelecer um determinado tipo de relação entre os entes de uma totalidade", 83 mesmo tendo presente que “a única característica comum desses entes seja o fato de serem livres”. ${ }^{84}$

Aqui é possível concluir, ainda com amparo na reflexão de Norberto Bobbio, que "a igualdade consiste apenas numa relação: o que dá a essa relação um valor, o que faz dela uma meta humanamente desejável, é o fato de ser justa”. ${ }^{85}$ Logo, a igualdade de oportunidades consiste em "introduzir artificialmente, ou imperativamente, discriminações que de outro modo não existiriam”, 86 porquanto "tem como objetivo colocar todos os membros daquela determinada sociedade na condição de participar da competição pela vida, ou pela conquista do que é vitalmente mais significativo, a partir de posições iguais". ${ }^{87}$ Assim, por igualdade de fato se entende "a igualdade com relação aos bens materiais, ou igualdade econômica, que é assim diferenciada da igualdade formal ou jurídica e da igualdade de oportunidades ou social”, 88 não obstante permaneça a necessidade de perquirir-se acerca da extensão e do alcance da "igualdade nos direitos", 89 visto que, cabe sempre ter presente, "significa algo mais do que a simples igualdade perante a lei enquanto exclusão de qualquer discriminação não justificada”. 90

Na Constituição Federal brasileira, editada pela Assembléia Nacional Constituinte em 5 de outubro de 1988, resultante de ampla mobilização e intensos debates em toda a sociedade brasileira, ${ }^{91}$ consta no caput do art. $5^{\circ}$ a pedra de toque que sustenta $o$

\footnotetext{
${ }^{80}$ BOBBIO, 1997a, p. 19.

${ }^{81}$ Ibid., p. 12.

${ }^{82}$ Ibid., p. 12

${ }^{83}$ Ibid., p. 13.

${ }^{84}$ Ibid., p. 13.

${ }^{85}$ Ibid., p. 15.

${ }^{86}$ Ibid., p. 32.

${ }^{87}$ BOBBIO, 1997a, p. 31.

${ }^{88}$ Ibid., p. 32.

${ }^{89}$ Ibid., p. 29

${ }^{90}$ Ibid.

${ }^{91}$ BONAVIDES, Paulo; ANDRADE, Paes de. História Constitucional do Brasil. 3. ed. Rio de Janeiro: Paz e Terra, 1991, p. 498: "Dados estatísticos estampados pelo Jornal do Brasil, de 3 de setembro de 1988, resumiram o exaustivo trabalho da Constituinte congressual: 200 mil emendas e pareceres, 21 mil discursos que excedem provavelmente o trabalho de todas as Constituintes anteriores. A mesma informação assinalava o vulto dos canais abertos para a Constituinte comunicar-se com o País, a saber, 712 programas do Diário da Constituinte, transmitidos por 170 estações de televisão e 700 programas da 'Voz da Constituinte', transmitidos por 2.000 emissoras de rádio. Segundo o mesmo jornal, a Primeira Secretaria da Mesa acumulou 28 mil notícias sobre a Constituinte, publicadas pelos oito jornais de maior circulação do País. Nunca, por conseguinte, em toda a nossa história constitucional, os trabalhos de uma assembléia nacional
} 
princípio da isonomia em nosso ordenamento jurídico, a qual se completa com diversos outros dispositivos constitucionais que, na lição de Afonso da Silva, "constituem reais promessas de busca da igualdade material”, 92 sendo oportuno transcrever o texto em foco, bem como o dos incisos I e VIII daquele artigo, eis que integram o "núcleo" deste direito fundamental constitucional e se irradiam para todo o sistema jurídico, ${ }^{93}$ estando assim formulados:

Art. $5^{\circ}$. Todos são iguais perante a lei, sem distinção de qualquer natureza, garantindo-se aos brasileiros e aos estrangeiros residentes no País a inviolabilidade do direito à vida, à liberdade, à igualdade e à propriedade, nos termos seguintes:

I. homens e mulheres são iguais em direitos e obrigações, nos termos desta Constituição;

[...]

VIII. ninguém será privado de direitos por motivo de crença religiosa ou de conviç̧ão filosófica ou política, salvo se as invocar para eximir-se de obrigação legal a todos imposta e recusar-se a cumprir prestação alternativa, fixada em lei;

(grifado nesta citação)

Diversos outros dispositivos constitucionais, conforme restará evidenciado, tratam da igualdade, sendo que a própria interpretação feita pela doutrina acerca do princípio da impessoalidade, insculpido na Constituição Federal no caput do art. 37 e detalhado nos incisos I, II e XXI, ${ }^{94}$ não é outra senão a do dever da administração de tratar com isonomia a todos, sendo esta a dicção de tais comandos constitucionais:

constituinte foram acompanhados cotidianamente de tão perto por um público de todas as camadas sociais quanto os da Constituinte de 88, tendo sido este sem dúvida um poderoso e influente fator de coadjuvação da presença participativa do povo, como deve ser em toda democracia moderna onde a utilização dos meios de comunicação se faz decisiva para incrementar e aparelhar a legitimação do processo nas esferas em que se exercitam de imediato formulações supremas de soberania.” Os autores ainda registram o pronunciamento do então líder do Partido da Social Democracia Brasileira (PSDB) na última sessão da Constituinte, Fernando Henrique Cardoso, que asseverou: "Pela primeira vez na História do Brasil e talvez do mundo, se faz uma Constituição com a colaboração direta da cidadania. Recebemos milhões de assinaturas em emendas populares e o povo sentiu de perto o que é consciência dos nossos direitos; entendeu, rapidamente, que, sem liberdade, não há avanço social. O Congresso foi durante a Constituinte um grande ponto de encontro de empresários, sindicalistas, representantes de igrejas, de nações indígenas, professores e estudantes. Foi uma amostra de todo o Brasil que, tocado pela consciência de que era hora de mudar, veio e pressionou. Se mais não fizemos, foi porque mais não pudemos” (Ibid., p. 497).

92 SILVA, José Afonso da. Curso de Direito Constitucional Positivo. 13. ed. São Paulo: Malheiros, 1997, p. 207.

${ }^{93}$ BASTOS, Celso Ribeiro; MARTINS, Ives Gandra. Comentários à Constituição do Brasil: promulgada em 5 de outubro de 1988. São Paulo: Saraiva, 1989, v. 2, p. 4. Acerca do sentido objetivo da proteção assentada no art. $5^{\circ}$ da CF, os autores esclarecem: "A nós sempre nos pareceu que o verdadeiro sentido da expressão 'brasileiros e estrangeiros residentes no País’ é deixar certo que esta proteção dada aos direitos individuais é inerente à ordem jurídica brasileira. [...]. É impensável que uma pessoa qualquer possa ser ferida em um destes bens jurídicos tutelados sem que as leis brasileiras lhe dêem a devida proteção” (Id. Ibid., p. 4).

${ }^{94} \mathrm{O}$ inciso XXI do art. 37 da CF versa acerca da igualdade nos processos de licitação pública estabelecendo que "ressalvados os casos especificados na legislação, as obras, serviços, compras e alienações serão contratados mediante processo de licitação pública que assegure igualdade de condições a todos os concorrentes, com cláusulas que estabeleçam obrigações de pagamento, mantidas as condições efetivas da proposta, nos termos da lei, o qual somente permitirá as exigências de qualificação técnica e econômica indispensáveis à 
Art. 37. A administração pública direta e indireta de qualquer dos Poderes da União, dos Estados, do Distrito Federal e dos Municípios obedecerá aos princípios de legalidade, impessoalidade, moralidade, publicidade e eficiência e, também, ao seguinte:

I. os cargos, empregos e funções públicas são acessíveis aos brasileiros que preencham os requisitos estabelecidos em lei, assim como aos estrangeiros, na forma da lei;

II. a investidura em cargo ou emprego público depende de aprovação prévia em concurso público de provas e títulos, de acordo com a natureza e a complexidade do cargo ou emprego, na forma prevista em lei, ressalvadas as nomeações para cargo em comissão declarado em lei de livre nomeação e exoneração;

E a identificação precisa do desiderato do caput do art. 37 da Constituição Federal é feita por Bandeira de Mello, quando aponta:

"Nele se traduz a idéia de que a Administração tem que tratar a todos os administrados sem discriminações, benéficas ou detrimentosas. Nem favoritismo nem perseguições são toleráveis. Simpatias ou animosidades pessoais, políticas ou ideológicas não podem interferir na atuação administrativa e muito menos interesses sectários, de facções ou grupos de qualquer espécie. O princípio em causa não é senão o próprio princípio da igualdade ou isonomia. Está consagrado explicitamente no art. 37, caput, da Constituição. Além disso, assim como "todos são iguais perante a lei” (art. $5^{\circ}$, caput), a fortiori teriam de sê-lo perante a Administração. ${ }^{95}$

Assim, é emblemática a reflexão de Otfried Höffe ao ponderar que "existem princípios de cuja justiça quase ninguém duvida", 96 ao que invoca o "mandamento de, num caso de conflito, ouvir o outro lado (audiatur et altera pars) e a proibição de ser juiz em causa própria (nemo judex in sua causa)", ${ }^{97}$ para concluir: "Tais princípios de procedimento são considerados justos pelo fato de servirem a um princípio de justiça superior que tampouco é controvertida, a imparcialidade (eqüidade)" ${ }^{98}$ No mesmo sentido Juarez Freitas identifica o princípio da igualdade na dicção constitucional "impessoalidade”, que também chama de imparcialidade, constante no caput do art. 37, quando assevera:

“O princípio da imparcialidade (que o constituinte preferiu denominar, impropriamente, princípio da impessoalidade), deriva do princípio geral da igualdade. Mister traduzi-lo como vedação constitucional de qualquer discriminação ilícita e atentatória à dignidade humana (quer dizer, vedação de toda discriminação

garantia do cumprimento das obrigações”. Correlacionado com este dispositivo está o disposto no art. 175 e seu parágrafo único, da CF, em que o caput preconiza: "Incumbe ao Poder Público, na forma da lei, diretamente ou sob regime de concessão ou permissão, sempre através de licitação, a prestação de serviços públicos.”

95 BANDEIRA DE MELLO, Celso Antônio. Curso de Direito Administrativo. 19. ed. São Paulo: Malheiros, 2005, p. 102.

${ }^{96}$ HÖFFE, Otfried. Justiça Política. Tradução: Ernildo Stein. Petrópolis: Vozes, 1991, p. 39.

${ }^{97}$ Ibid.

${ }^{98}$ HÖFFE, 1991, p. 39. 
negativa, mostrando-se lícitas apenas as ações afirmativas ou discriminações inversas ou positivas, que estabeleçam quotas, por exemplo, de modo comedido, inteligente e proporcional). Segundo o princípio, a Administração Pública precisa dispensar um tratamento isonômico a todos, sem privilégios espúrios, tampouco qualquer manobra persecutória. Quer-se a instauração, acima de sinuosos personalismos (sem prejuízo da valorização diferencial do bom agente público), do governo dos princípios, em lugar de idiossincráticos projetos de cunho particularista e antagônico à consecução do bem viver. ${ }^{99,}$

É imprescindível, portanto, destacar a dignidade da pessoa humana, consagrada no inciso III do art. $1^{\circ}$ da Constituição Federal enquanto fundamento da República Federativa do Brasil, ${ }^{100}$ pois, conforme Ingo Sarlet observa, "também o princípio isonômico (no sentido de tratar os desiguais de forma desigual) é, por sua vez, corolário direto da dignidade", ${ }^{101}$ ao que o mesmo autor aduz, acerca da justiça social e da existência digna, que:

“[...] no âmbito de uma "função protetiva” (e, portanto, defensiva) da dignidade - situa-se a noção de que a dignidade da pessoa humana constitui um dos critérios materiais para a aferição da incidência de uma proibição de retrocesso em matéria de direitos fundamentais, notadamente (mas não exclusivamente) na esfera dos direitos fundamentais sociais de cunho prestacional. ${ }^{102,}$

É, neste particular, digna de nota a obra de Joaquim Barbosa, Ação afirmativa \& princípio constitucional da igualdade, na qual sustenta a complementariedade filosófica entre a perspectiva individual e a de grupo ou coletiva na afirmação constitucional e infraconstitucional antidiscriminação. Logo, o autor pondera que:

“A proteção e a promoção da dignidade do indivíduo enquanto tal constituem, é certo, um objetivo constitucional de primeira ordem. Isto, no entanto, não exclui a adoção de institutos e mecanismos suscetíveis de promover o avanço de direitos do grupo, o que, como se sabe, contribui mais eficazmente para a disseminação do bem-estar geral da coletividade. ${ }^{103 \text {, }}$

Assim, é sobremaneira relevante identificar a supremacia do princípio da igualdade substantiva nos objetivos fundamentais da República Federativa do Brasil, em que nos incisos III e IV do art. $3^{\circ}$ da Carta Magna há uma significativa referência ao que se entende como igualdade de fato enquanto uma meta a ser perseguida em caráter permanente pela nação brasileira. Eis que nestes termos dispõem tais comandos constitucionais:

${ }^{99}$ FREITAS, Juarez. O controle dos atos administrativos e os princípios fundamentais. 3. ed. São Paulo: Malheiros, 2004a, pp. 49-50.

${ }^{100}$ CF: Art. $1^{\circ}$ A República Federativa do Brasil, formada pela união indissolúvel dos Estados e Municípios e do Distrito Federal, constitui-se em Estado Democrático de Direito e tem como fundamentos: [...] III - a dignidade da pessoa humana;

${ }^{101}$ SARLET, Ingo Wolfgang. Dignidade da pessoa humana e direitos fundamentais na Constituição Federal de 1988. 5. ed. Porto Alegre: Livraria do Advogado, 2007, p. 135.

${ }^{102}$ Ibid., 2007, pp. 124-125.

${ }^{103}$ BARBOSA GOMES, Joaquim B. Ação afirmativa \& princípio constitucional da igualdade: o direito como instrumento de transformação social. A experiência dos EUA. São Paulo: Renovar, 2001, p. 79. 
Art. $3^{\circ}$. Constituem objetivos fundamentais da República Federativa do Brasil:

[...]

III. erradicar a pobreza e a marginalização e reduzir as desigualdades sociais e regionais;

IV. promover o bem de todos, sem preconceitos de origem, raça, sexo, cor, idade e quaisquer outras formas de discriminação.

A igualdade substantiva também se faz presente enquanto objetivo da ordem econômica, especialmente nos termos do disposto no art. 170 e nos seus incisos VII, VIII, IX e parágrafo único da Constituição Federal, ${ }^{104}$ em que se identifica, conforme a doutrina de Eros Grau, que há uma "ideologia, perfeitamente determinável e definível no bojo do discurso constitucional”, ${ }^{105}$ razão pela qual a mesma

“[...] vincula o intérprete, de sorte precisamente, a repudiar a postura, aludida por Canotilho, assumida por quantos optam por concepções ideológicas dela diferentes, e a ensejar o exercício, pelo mesmo Canotilho referido, de um prudente positivismo, indispensável à manutenção da obrigatoriedade normativa do texto constitucional. ${ }^{106,}$

E diferente não se dá quanto ao disposto nos incisos XXX, XXXI, XXXII e XXXIV do art. $7^{\circ}$ da Constituição Federal, ${ }^{107}$ porquanto tais comandos se apresentam em plena sintonia com os princípios da ordem econômica "fundada na valorização do trabalho" (CF, art. 170, caput). São representativas, quanto ao sentido consciente da opção do Poder Constituinte de 1988, as seguintes palavras de Eros Grau acerca do constitucionalismo do séc. XIX:

"As Constituições liberais não necessitavam, no seu nível (delas, Constituições liberais), dispor, explicitamente, normas que compusessem uma ordem econômica constitucional. A ordem econômica existente no mundo do ser não merecia reparos. Assim, bastava o que definido, constitucionalmente, em relação à propriedade

${ }^{104}$ CF: “Art. 170. A ordem econômica , fundada na valorização do trabalho humano e na livre iniciativa, tem por fim assegurar a todos existência digna, conforme os ditames da justiça social, observados os seguintes princípios: [...] VII - redução das desigualdades regionais e sociais; VIII - busca do pleno emprego; IX - tratamento favorecido para as empresas de pequeno porte constituídas sob as leis brasileiras e que tenham sua sede e administração no País. Parágrafo único. É assegurado a todos o livre exercício de qualquer atividade econômica, independentemente de autorização de órgãos públicos, salvo nos casos previstos em lei.”

${ }^{105}$ GRAU, Eros Roberto. A ordem econômica na Constituição de 1988: interpretação e crítica. São Paulo: Revista dos Tribunais, 1990, p. 194. O autor esclarece o sentido de ideologia que emprega citando Washington Peluso Albino de Souza, que, em seu Direito econômico, refere esta enquanto "conjunto harmônico de princípios que vão inspirar a própria organização da vida social, segundo o regime que irá regê-la” (Ibid., p. 194). ${ }^{106}$ Ibid., pp. 194-195.

${ }^{107}$ CF: "Art. $7^{\circ}$ São direitos dos trabalhadores urbanos e rurais, além de outros que visem à melhoria de sua condição social: [...] XXX - proibição de diferença de salários, de exercício de funções e de critério de admissão por motivo de sexo, idade, cor ou estado civil; XXXI - proibição de qualquer discriminação no tocante a salário e critérios de admissão do trabalhador portador de deficiência; XXXII - proibição de distinção entre trabalho manual, técnico e intellectual ou entre os profissionais respectivos; XXXIII - proibição de trabalho noturno, perigoso ou insalubre a menores de 16 (dezesseis) anos, salvo na condição de aprendiz, a partir de 14 (quatorze) anos; XXXIV - igualdade de direitos entre o trabalhador com vínculo empregatício permanente e o trabalhador avulso.” 
privada e à liberdade contratual, ao quanto, não obstante, acrescentava-se umas poucas outras disposições veiculadas no nível infraconstitucional, confirmadoras do capitalismo concorrencial, para que se tivesse composta a normatividade da ordem econômica liberal. ${ }^{108,}$

Feitas as colocações pertinentes ao objetivo constitucional de afirmação de uma maior igualdade substantiva, cumpre referir, especificamente no âmbito das garantias constitucionais, o disposto no inciso LIV ${ }^{109}$ do art. $5^{\circ}$ da Constituição Federal, pois a garantia do “devido processo legal” expressa inequívoca igualdade de gozo dos mesmos direitos e assegura a própria imparcialidade do Estado, que procederá com isenção nas mesmas condições e circunstâncias institucionais. ${ }^{110}$ Nesse particular resta patente que mesmo os aspectos formais do princípio da isonomia expressam um sentido material, dado que nenhuma justiça verdadeira pode contentar-se com os aspectos puramente formais, no que mais uma vez toma relevo a reflexão de Norberto Bobbio, quando assevera:

“Não há nada de particularmente progressista ou reacionário no fato de que os jogadores de canastra ou de pôquer comecem o jogo com o mesmo número de cartas, ou os jogadores de xadrez com o mesmo número e o mesmo tipo de peças, ou que os duelantes disponham da mesma arma, os concorrentes partam da mesma linha, ou os participantes de um concurso devam ter o mesmo diploma, devam ler para o exame os mesmos livros e sejam todos obrigados a não conhecer o tema que cairá no exame. ${ }^{111 \text { ”, }}$

A questão que se coloca é quanto aos limites dessa igualdade formal, o que, conforme foi apontado, somente será superado com a conjugação de todos os princípios constitucionais informadores da ordem jurídica, porque nela reside a afirmação de uma igualdade substantiva. Assim, a dupla referência ao denotado “princípio dos princípios” no próprio caput do art. $5^{\circ}$ da Constituição Federal - todos são iguais na igualdade - não é algo inútil, mas do qual se depreendem os aspectos formal e material da isonomia. Esta é a precisa constatação de Souto Borges ao observar que "constitucionalmente a igualdade garante a igualdade", ${ }^{112}$ pois o próprio conteúdo de cada lei abriga a isonomia, no que consiste a igualdade na fruição do sentido material do direito em questão, sendo identificada enquanto "igualdade na lei", ${ }^{113}$ mas assegurada pela igualdade formal, identificada enquanto "igualdade perante a lei". ${ }^{114}$ Assim, o autor observa que:

${ }^{108}$ GRAU, 1990, p. 75.

${ }^{109}$ CF: “Art. $5^{\circ}$ [...] LIV - ninguém será privado da liberdade ou de seus bens sem o devido processo legal;”.

${ }^{110} \mathrm{CF}$ : “Art. $5^{\circ}$ [...] XXXVII - não haverá juízo ou tribunal de exceção; [...] LIII - ninguém será processado nem sentenciado senão pela autoridade competente;”.

${ }^{111}$ BOBBIO, 1997a, p. 31.

${ }^{112}$ BORGES, José Souto Maior. Princípio da isonomia e sua significação na Constituição de 1988. Revista de Direito Público, São Paulo, v. 23, nº 93, jan./mar. 1990, p. 38.

${ }^{113}$ BORGES, 1990, p. 38. Bobbio adota a designação, que parece ser mais apropriada, de "igualdade nos direitos (também formulada como dos direitos)", conforme se verifica na nota 75.

${ }^{114}$ Ibid., 1990, p. 38. O autor fala no mesmo sentido empregado por Norberto Bobbio, conforme se verifica na notas 73 e 74 . 
“Torna-se manifesto por essa via que a Constituição Federal, no seu art. 5º estrutura $\mathrm{a}$ isonomia de modo refinadamente complexo. Primeiro como um direito à reta aplicação da lei (princípio formal). Segundo, como um princípio cujo conteúdo (não a mera forma de sua aplicação portanto) é inegavelmente amplo e até inexceptuável, pela vedação de distinções de qualquer natureza (princípio material e pessoal). Terceiro porque ela regula também os meios assecuratórios desse direito (a lei e outros atos normativos, como as sentenças judiciais). ${ }^{115,}$

No mesmo sentido anda o constitucionalista português Jorge Miranda quando adverte que "igualdade perante a lei não é igualdade exterior à lei"116 e observa que o princípio da isonomia restringe a atuação do próprio legislador, dado que:

“É antes de tudo, igualdade na lei. Tem por destinatários, desde logo, os próprios órgãos de criação do Direito. [...]. Toda a lei ordinária deve obedecer ao princípio, tanto nas suas precipitações imediatas de igualização e diferenciação como no seu conteúdo geral. E a lei deve não tanto enquadrar-se silogisticamente nos comandos da Constituição quanto adstringir-se aos seus fins. ${ }^{117}$,"

Logo, é de conclusão singela que a primeira referência ao princípio da igualdade, constante no caput do art. $5^{\circ}$ da Constituição Federal - Todos são iguais perante a lei -, identifica um direito, cuja aplicação é imediata nos termos do $\S 1^{\circ}$ do mesmo artigo, em que o sentido formal (igualdade perante a lei) ali constante irá assegurar o sentido material (igualdade nos direitos) constante na segunda referência. E tal sentido material, assegurado pela garantia da inviolabilidade do direito à igualdade, contempla, portanto, todos os direitos fundamentais previstos na Constituição, ${ }^{118}$ sendo, na referência de Gomes Canotilho ao "princípio da universalidade", 119 "direitos de todos", ${ }^{120}$ dado que são "direitos humanos e não apenas direitos dos cidadãos"121 ou de alguns brasileiros, direitos em que se manifesta o próprio dever de tratar desigualmente os desiguais. Assim, o dever de tratar desigualmente os desiguais é balizado pelo conjunto de princípios que constituem a coerência de toda a ordem constitucional, ainda que Norberto Bobbio lembre que essa universalidade não significa o reconhecimento de fato de tais direitos, ${ }^{122}$ o que por certo é tarefa dos seres humanos, e não da metafísica.

\section{ISONOMIA E FATORES JURÍDICOS DE DISCRIMINAÇÃO}

Diante da valoração constitucional e da importância do princípio da isonomia para a ordem jurídica brasileira, Calmon de Passos observa que "a igualdade absoluta entre os homens encontra desmentidos inafastáveis quer em tudo quanto a ciência nos põe como saber, quer em tudo quanto a reflexão filosófica nos infunde como sabedoria”, ${ }^{123}$

\footnotetext{
115 Ibid., p. 38.

${ }^{116}$ MIRANDA, Jorge. Manual de Direito Constitucional. 3. ed. Coimbra: Coimbra, 2000, v. 4 , p. 241.

117 Ibid.

${ }^{118}$ BOBBIO, 1997a, p. 29. Vide nota 64.

${ }^{119}$ CANOTILHO, 2003, p. 416.

${ }^{120}$ Ibid., p. 416.

${ }^{121}$ Ibid., pp. 416-417.

${ }^{122}$ BOBBIO, 1997a, p. 29.

${ }^{123}$ CALMON DE PASSOS, J. J. O princípio de não discriminação. Jus Navigandi, no 57 (07.2002).

Disponível em: http:// www1.jus.com.br/doutrina/texto.asp?id=2990. Acesso em: 25 nov. 2004.
} 
de tal modo que o próprio jurista da Bahia observa que há uma disciplina conjunta e um "estreito nexo entre não discriminação e igualdade". ${ }^{124}$ Os dois princípios expressam a delimitação permanente e quotidiana das “discriminações desautorizadas"125 diante da "diferenciação aceitável, porque compensadora," 126 no que incide a árdua tarefa do hermeneuta em face da complexidade da realidade no contexto da ordem jurídica constitucional. Assim, o princípio de não discriminação "não tem consistência própria, mas é uma aparente derrogação do princípio da igualdade, em face da inelutável necessidade prática de termos que tratar diferentemente os homens para igualá-los”. ${ }^{27}$ É, portanto, imperativo considerar os próprios fatores de discriminação inseridos no ordenamento jurídico constitucional enquanto "um consectário ou reflexo do princípio da igualdade”. ${ }^{128}$

Neste sentido Humberto Ávila observa que "a aplicação da igualdade depende de um critério diferenciador e de um fim a ser alcançado", ${ }^{29}$ razão por que "fins diversos levam à utilização de critérios distintos, pela simples razão de que alguns critérios são adequados à realização de determinados fins; outros não", ${ }^{130}$ de tal modo que:

“A concetização do princípio da igualdade depende do critério-medida objeto de diferenciação. Isso porque o princípio da igualdade, ele próprio, nada diz quanto aos bens ou aos fins de que se serve a igualdade para diferenciar ou igualar as pessoas. As pessoas ou situações são iguais ou desiguais em função de um critério diferenciador. ${ }^{131,}$

E tal se dá diante da sociabilidade do ser humano, pela qual "temos condições de definir o que os faz iguais ou reclama que como iguais sejam tratados”, ${ }^{132,133}$ sendo que "no particular da não discriminação, comportamento idêntico é impensável", ${ }^{134}$ pois "a igualdade substancial é um objetivo constitucionalmente tutelado", ${ }^{135}$ de tal modo que, para igualar substancialmente pessoas diferenciadas entre, si Calmon de Passos observa:

“A única solução é desigualá-las em termos jurídicos para que através desse desigual tratamento se obtenha maior igualdade substancial. Desigualar nesses termos é permanecer fiel ao princípio constitucional da igualdade e seu consectário lógico, o princípio de não discriminação. Desigualar em termos diversos é

\footnotetext{
${ }^{124}$ CALMON DE PASSOS, 2002.

${ }^{125}$ Ibid.

${ }^{126}$ Ibid.

${ }^{127}$ Ibid.

${ }^{128}$ Ibid.

129 ÁVILA, Humberto. Teoria dos princípios: da definição à aplicação dos princípios jurídicos. 3. ed. São Paulo: Malheiros, 2004, p. 101.

${ }^{130}$ ÁVILA, 2004, p. 102.

${ }^{131}$ Ibid.

${ }^{132}$ CALMON DE PASSOS, 2002

${ }^{133}$ É oportuno lembrar o registro de Norberto Bobbio diante da igualdade de fato: "os homens são mais iguais entre si (ou menos diversos) com relação às necessidades do que, por exemplo, com relação às capacidades” (BOBBIO, 1997a, p. 34).

${ }^{134}$ CALMON DE PASSOS, op. cit.

135 Ibid.
} 
discriminar, o que está constitucionalmente vetado. Ali, o tratamento desigual deixou de ser discriminador, por ter produzido maior igualdade como resultado. Na segunda hipótese, o tratamento desigual se macula de inconstitucional, por oferecer como resultado a manutenção da desigualdade anterior ou sua exasperação, ou a instituição de desigualdade nova antes inexistente. ${ }^{136,}$

Neste aspecto cabe referir a lição de Gomes Canotilho acerca da "função de não discriminação", pela qual se constata o que segue:

"Uma das funções dos direitos fundamentais ultimamente mais acentuada pela doutrina (sobretudo a doutrina norte-americana) é a de que se pode chamar função de não discriminação. A partir do princípio da igualdade e dos direitos de igualdade específicos consagrados na constituição, a doutrina deriva esta função primária e básica dos direitos fundamentais: assegurar que o Estado trate os seus cidadãos como cidadãos fundamentalmente iguais. Esta função de não discriminação alarga-se a todos os direitos. Tanto se aplica aos direitos, liberdades e garantias pessoais (ex: não discriminação em virtude de religião), como aos direitos de participação política (ex: direito de acesso aos cargos públicos) como ainda aos direitos dos trabalhadores (ex: direito ao emprego e formação profissional). Alarga-se de igual modo aos direitos a prestações (prestações de saúde, habitação). É com base nesta função de discriminação que se discute o problema das quotas (ex: "parlamento paritário de homens e mulheres”) e o problema das afirmative actions tendentes a compensar a desigualdade de oportunidades (ex: quota de deficientes). É ainda com uma acentuação-radicalização da função antidiscriminatória dos direitos fundamentais que alguns grupos minoritários defendem a efectivação plena da igualdade de direitos numa sociedade multicultural e hiperinclusiva (“direitos dos homossexuais", "direitos das mães solteiras", "direitos das pessoas portadoras de HIV”). ${ }^{137, "}$

Aqui toma destaque o significativo trabalho de análise e classificação estritamente jurídica desta matéria, concebido por Bandeira de Mello, na qual o doutrinador explicita que quaisquer elementos residentes nas coisas, pessoas ou situações, desde que haja correlação lógica com a igualdade pretendida e compatibilidade com os princípios constitucionais, ${ }^{138}$ podem justificar um tratamento discriminatório, porque "não é no traço de diferenciação que se deve buscar algum desacato ao princípio isonômico." "139 Com isso o autor afasta qualquer elemento ou processo arbitrário de discriminação e demonstra que "por via do princípio da igualdade, o que a ordem jurídica pretende

\footnotetext{
${ }^{136}$ Ibid.

${ }^{137}$ CANOTILHO, 2003, pp. 409-410.

${ }^{138}$ BANDEIRA DE MELLO, Celso Antônio. Conteúdo jurídico do princípio da igualdade. 3. ed. São Paulo: Malheiros, 2004, p. 21. O autor aponta, dentre outros, o seguinte exemplo: "Pode-se, ainda, supor que grassando em uma região uma epidemia, a que se revelem resistentes os indivíduos de certa raça, a lei estabeleça que só poderão candidatar-se a cargos públicos de enfermeiro, naquela área, os indivíduos pertencentes à raça refratária à contração da doença que se queira debelar. É óbvio, do mesmo modo, que, ainda aqui, as pessoas terão sido discriminadas em razão da raça, sem, todavia, ocorrer, por tal circunstância, qualquer hostilidade ao preceito igualitário que a Lei Magna desejou prestigiar” (Ibid., p. 16).

${ }^{139}$ Ibid., p. 17.
} 
firmar é a impossibilidade de desequiparações fortuitas ou injustificadas”. ${ }^{140}$ Neste particular calha a reflexão de Sérgio Porto no tocante ao princípio da proporcionalidade, porquanto tal postulado, lastreado no “devido processo legal” previsto no inciso LIV do art. $5^{\circ}$ da Constituição Federal, orienta o hermeneuta e o próprio legislador, dado que:

“[...] tem por escopo - como sua designação deixa antever - a vontade de evitar resultados desproporcionais e injustos, baseado em valores fundamentais conflitantes, ou seja, o reconhecimento e a aplicação do princípio permitem vislumbrar a circunstância de que o propósito constitucional de proteger determinados valores fundamentais deve ceder quando a observância intransigente de tal orientação importar a violação de outro direito fundamental ainda não valorado. ${ }^{141,}$

Assim, a discriminação pode e deve ser compatível com a isonomia quando existe um vínculo de correlação lógica entre a peculiaridade diferencial acolhida, por residente no objeto, e a desigualdade de tratamento em função dela conferida, ${ }^{142}$ desde que tal correlação não seja incompatível com interesses prestigiados na Constituição, ${ }^{143}$ de modo que não podem ser feitas diferenciações, sem violação da isonomia, quando não estiver presente:

\section{a) Um fator de desigualação em que:}

- a lei guarde seu caráter geral quanto aos destinatários e não esteja erigida em “critério diferencial um traço tão específico que singularize no presente e definitivamente, de modo absoluto, um sujeito a ser colhido pelo regime peculiar;”144

- o traço diferencial adotado pela lei resida "na pessoa, coisa ou situação a ser discriminada; ou seja: elemento algum que não exista nelas mesmas poderá servir de base para sujeitá-las a regimes diferentes”, ${ }^{145}$ tal como, v.g., o fator tempo. ${ }^{146}$

b) Uma justificativa racional (fundamento lógico): correlação lógica abstrata existente entre o fator erigido em critério de discrímen e a disparidade estabelecida no tratamento jurídico diversificado. ${ }^{147}$

c) A consonância desta correlação lógica com os interesses absorvidos no sistema constitucional: a correlação ou fundamento racional abstratamente existente deve ser aferida in concreto. ${ }^{148}$

d) A necessária cautela na interpretação das leis em atenção à isonomia. ${ }^{149}$

\footnotetext{
${ }^{140}$ Ibid., p. 18.

${ }^{141}$ PORTO, Sérgio Gilberto. Cidadania processual e relativização da coisa julgada. Revista Jurídica, v. 51, $\mathrm{n}^{\circ}$ 304, pp. 23-31, fev. 2003, p. 24.

${ }^{142}$ BANDEIRA DE MELLO, 2004, p. 37.

${ }^{143}$ Ibid., p. 43.

${ }^{144}$ Ibid., p. 23.

${ }^{145}$ Ibid., p. 23.

${ }^{146}$ Ibid., p. 30: “O fator ‘tempo' não é jamais um critério diferencial, ainda que em primeiro relanço aparente possuir este caráter.”

${ }^{147}$ Ibid., p. 37.

${ }^{148}$ Ibid., p. 41.

${ }^{149}$ Ibid., p. 46.
} 
Aqui cabe analisar cada um dos elementos autorizadores das diferenciações que busquem igualar situações de fato diferenciadas, conforme se faz a seguir:

1) $\boldsymbol{O}$ fator de desigualação. É inviável, no aspecto lógico, a norma que singulariza uma situação atual irreproduzível, como, v.g., quando descreve uma situação já ocorrida apenas com um indivíduo determinado ou então demonstra haver uma inviabilidade apenas material de quando a hipótese se pode repetir, mas é improvável. Assim, é necessário considerar que:

“a) A regra apenas geral nunca ofende a isonomia.

b) A regra abstrata também não viola a isonomia, dado que a renovação da hipótese normativa acarreta sua incidência sempre sobre toda uma categoria de indivíduos, como, v.g., a norma que assevera que ao completar 18 anos os homens devem se alistar no serviço militar.

c) A regra individual poderá ou não se incompatibilizar com o princípio da igualdade, pois será possível se referir sujeito futuro, portanto atualmente indeterminado e indeterminável, como, v.g., as normas que dispõem acerca da excepcionalidade da subvenção para quem for ex-presidente ou ex-governador.

d) A regra concreta também será possível quando, além de concreta, for geral, como, v.g., aquela que racional e motivadamente, por aspectos culturais e históricos, assevera que todas as casas de uma vila devem ser pintadas de uma determinada cor."

São incabíveis regimes diferentes determinados em vista de fator alheio às pessoas, pois, conforme já referido, a discriminação não se pode dar em face da demarcação espacial, mas no que nela existe. Quando a lei faz referência ao tempo, aparentemente tomando-o como elemento para discriminar situações ou indivíduos abrangidos pelo período demarcado, o que na verdade se está prestigiando como fator de desequiparação é a própria sucessão de fatos ou de “estados” transcorridos ou a transcorrer. Trata-se da diferença entre existir e não existir (ter ocorrido ou não ter ocorrido), a que o direito empresta força de fator distintivo entre as situações para lhes atribuir disciplinas diversas, de tal modo que o tempo, por si só, é elemento neutro, enquanto que os fatos ou situações que nele transcorreram e são por ele demarcados, estes sim é que são e podem ser erigidos em fatores de discriminação. A lei não pode tomar tempo ou data como fator de discriminação entre pessoas a fim de lhes dar tratamento desigual. As diferenças de tratamento só se justificam perante fatos e situações diferentes. Há de ser tomado em conta, nos próprios acontecimentos, as diferenças justificadoras de direitos e deveres distintos e não em fatores alheios a eles que em nada lhes agregam peculiaridades desuniformizadoras.

2) A justificativa racional. É necessário que exista uma correlação lógica entre o fator de discrímen e a desequiparação. A igualdade é agredida quando o fator diferencial adotado para qualificar os atingidos pela regra não guarda relação de pertinência lógica com a inclusão ou exclusão no benefício deferido ou com a inserção ou arredamento do gravame imposto. Se o fator diferencial não guardar conexão lógica com a disparidade de tratamentos jurídicos dispensados, a distinção estabelecida afronta o princípio da isonomia. A lei não pode conceder tratamento específico, vantajoso ou desvantajoso, 
em atenção a traços e circunstâncias peculiarizadoras de uma categoria de indivíduos, se não houver adequação racional entre o elemento diferencial e o regime dispensado aos que se inserem na categoria diferençada. A correlação lógica a que se aludiu nem sempre é absoluta, “pura”, a dizer, isenta da penetração de ingredientes próprios das concepções da época, absorvidos na intelecção das coisas.

3) A consonância da correlação lógica entre o fator de discrímen e a desequiparação com os interesses absorvidos no sistema constitucional. Para que um discrímen legal possa conviver com a isonomia, é necessário que se verifiquem quatro elementos, sendo eles a generalidade; a efetiva existência da desequiparação; a correlação lógica, em abstrato, entre a desequiparação e o regime jurídico diferenciado; a pertinência, diante do texto constitucional, do vínculo de correlação em foco na situação concreta.

Não é qualquer diferença, conquanto real e logicamente explicável, que justifica tais discriminações legais. Reversamente, não podem ser colocadas em desvantagem pela lei situações a que o sistema constitucional empresta conotação positiva, de tal modo que, nas palavras de Bandeira de Mello, tal nexo lógico exige que se "retrate concretamente um bem - e não um desvalor - absorvido no sistema normativo constitucional”. ${ }^{150} \mathrm{O}$ autor exemplifica referindo o fato de que as indústrias de grande porte produzem em mais escala e são mais competitivas, mas os incentivos fiscais nem por isto devem privilegiá-las, pois a Constituição hostiliza as situações propiciadoras do domínio dos mercados e da eliminação da livre concorrência (art. 170 e 173, § 4º, da CF). ${ }^{151}$

4) A necessária cautela na interpretação das leis em atenção à isonomia. Não é possível interpretar como desigualadas legalmente certas situações, quando a lei não haja "assumido" o fator tido como desequiparador. Se a lei distingue pessoas, situações, grupos, e se tais diferenciações se compatibilizam com os princípios expostos, não há como negar tais discrimens, entretanto, quando a distinção não procede diretamente da lei que instituiu o benefício ou exonerou determinada pessoa ou categoria de pessoas de encargo, não tem sentido prestigiar interpretação que favoreça a contradição do mais solene dos princípios constitucionais.

Na síntese de Bandeira de Mello, cabe lembrar que "a isonomia se consagra como o maior dos princípios garantidores dos direitos individuais, de tal modo que é preciso que se trate de desequiparação querida, desejada pela lei, ou, ao menos, pela conjugação harmônica das leis”, ${ }^{152}$ ao que se acresce a lição de Calmon de Passos diante da singularidade de cada ser humano:

"Essa dimensão personalíssima de cada ser humano é um complicador do princípio da igualdade, porquanto ela pode levar, paradoxalmente, a que o tratamento objetivamente justo, porque matematicamente igualitário, seja sentido pessoalmente como injusto por quem a ele submetido. O princípio da igualdade, portanto, consiste na procura e definição dos fatores externos mediante os quais se pode

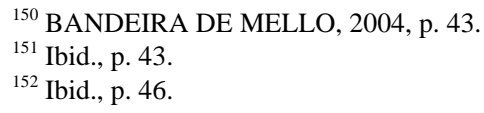


ter uma “moeda” política que permita igualar homens essencialmente diferentes, sob inúmeros aspectos, tanto biológica quanto psicologicamente, tanto em termos materiais quanto em dimensão cultural. A discriminação é a utilização de "moeda falsa” para esse intercâmbio jurídico-político, que está vetado pelo princípio de não discriminação. ${ }^{153}$,"

A máxima substantiva geral de igualdade representa, portanto, um limite ao arbítrio, de tal modo que, para Robert Alexy, sua essência reside na fórmula proibição de tratamentos arbitrariamente desiguais. ${ }^{154}$ A dificuldade de uma subsunção diante de uma análise geral do arbítrio recomenda, todavia, uma estrita incidência do preceito da igualdade mediante termos de comparação, ${ }^{155}$ dado que se trata de "un principio de igualdad que, prima facie, exige un tratamiento igual y solo permite un tratamiento desigual si puede ser justificado con razones opuestas."156

\section{IGUALDADE E OS FATORES SEXO, RAÇA, CREDO RELIGIOSO}

Uma vez analisada a relação entre a isonomia e os fatores de discriminação, importa observar que a Constituição Federal, ainda nas palavras de Bandeira de Mello, "recolheu na realidade social elementos que reputou serem possíveis fontes de desequiparações odiosas e explicitou a impossibilidade de virem a ser destarte utilizados", ${ }^{57}$ sendo que o mesmo doutrinador aponta outros fatores que estão na generalidade da regra, como a renda, a origem familiar, a compleição corporal. ${ }^{158}$

A consagração, em nossa ordem jurídica, do teor do disposto no inciso VIII do art. $5^{\circ}$ da Constituição Federal, em que reside a explícita vedação de qualquer tratamento discriminatório "por motivo de crença religiosa ou de convicção filosófica ou política”, resulta da experiência histórica diante da triste reiteração destes fatores de desigualdade em contraposição com a crescente marca infamante que ostentam na consciência cultural e social dos povos. É, como se observa, uma reiteração do princípio da isonomia diante de uma variável do que Norberto Bobbio identifica como "as três fontes principais de desigualdade entre os homens: a raça (ou, de modo mais geral, a participação num grupo étnico ou nacional), o sexo e a classe social”. ${ }^{159}$

E o fator credo religioso, inerente ao indivíduo e suas convicções, afinidades e escolhas mais íntimas, também está presente na idéia de grupo, de tal modo que reside na tolerância religiosa e no caráter laico do Estado ${ }^{160}$ a origem de um dos

${ }^{153}$ CALMON DE PASSOS, 2002.

${ }^{154}$ ALEXY, 1997, p. 394: “están prohibidos los tratamientos arbitrariamente desiguales."

155 Ibid., p. 389.

${ }^{156}$ ALEXY, 1997, p. 398.

${ }^{157}$ BANDEIRA DE MELLO, 2004, p. 18.

${ }^{158}$ Ibid., 2004, p. 18.

${ }^{159}$ BOBBIO, 1997a, p. 43

${ }^{160}$ Neste sentido é significativo o voto do Ministro Sepúlveda Pertence na ADIn n ${ }^{\circ}$ 2806-RS, patrocinada pelo Governador do Estado do Rio Grande do Sul contra a Lei $n^{\circ}$ 11.830/2002, que impunha "adequação das atividades do serviço público estadual e dos estabelecimentos de ensino públicos e privados aos dias de guarda das diferentes religiões professadas no Estado", a qual foi acolhida por unanimidade pelo Excelso Pretório: "Sr. Presidente, estou de pleno acordo com o eminente Relator, mas creio que a lei tem implicações maiores do que o simples problema de iniciativa legislativa. Pergunto: seria constitucional uma lei de iniciativa do Poder Executivo que subordinasse assim o andamento da administração pública aos 'dias de guarda' 
grandes vetores de afirmação dos direitos humanos e neles da própria idéia de igualdade em decorrência da condenação pública do ódio e da recusa do outro na história da humanidade. É, assim, na liberdade religiosa e na respectiva tolerância que a antecede e assegura, que se encontra a mais significativa expressão do respeito pela dignidade humana na sua essência mais singular e subjetiva. Nesse sentido Peces-Barba e outros apontam que "la tolerância, precursora de la libertad religiosa, será el primer derecho fundamental", ${ }^{161}$ sendo que "los derechos fundamentales se iniciarán en três âmbitos”, ou seja: ${ }^{162}$

"En la reflexión de la tolerancia para poner fin al enfrentamiento religioso; sobre los limites del poder, ante el fortalecimiento del Estado como poder absoluto y sobre la necesaria humanización en el ámbito penal y procesal por su situación de inseguridad, de interdeterminación de las penas, de utilización de la tortura como forma de averiguación de la verdad y como pena, en definitiva por la falta de garantías. ${ }^{163 \text {, }}$

Cabe ainda destacar que a garantia do disposto no inciso VIII do art. $5^{\circ}$ da Constituição Federal é reforçada pelos comandos dos incisos XLI e XLII do mesmo artigo, nos quais consta, respectivamente, que “a lei punirá qualquer discriminação atentatória dos direitos e liberdades fundamentais" e que "a prática do racismo constitui crime inafiançável e imprescritível, sujeito à pena de reclusão, nos termos da lei”. Neste aspecto é significativa uma pequena grande obra, pois com magistral habilidade e em apertada síntese, Ricardo Camargo, em seu Interpretação jurídica e estereótipos, situa o problema universal da hermenêutica em nosso tempo, no que os limites humanos no fazer justiça se agravam diante da referida crise de racionalidade, o que é bem diagnosticado nesta passagem:

“Na ética como na estética, o estereótipo é a matéria-prima do preconceito e de todas as ações nele embasadas. Por estereótipo, nesta obra, entendo o rótulo que se aplica a uma idéia, coisa ou pessoa, pouco importando se pertinente ou não tal aplicação. Sua utilização, em que pese mais corriqueira em leigos que se debrucem sobre o assunto a que são aplicados, é freqüente também entre os especialistas, entre os quais doutos, sem que, no entanto, se lhes possa censurar por isto, salvo quando evidente (!) o dolo. ${ }^{164,}$

Reside, portanto, sobremaneira na liberdade religiosa e de convicção filosófica e política, bem como na igualdade racial e de gênero, a idéia de uma sociedade multicultural; entretanto, a superação das contradições decorrentes de barreiras e

religiosos? Seria razoável, malgrado fosse a iniciativa do governador, acaso crente de alguma fé religiosa que faz os seus cultos na segunda-feira à tarde, que todos esses crentes teriam direito a não trabalhar na segunda-feira e pedir reserva de outra hora para o seu trabalho? É desnecessário à conclusão, mas considero realmente violados, no caso, princípios substanciais, a partir do ‘due process' substancial e do caráter laico da República. Deixo claro que também julgo a lei materialmente inconstitucional” (JSTF, LEX-296, pp. 73-79/Tribunal Pleno, DJU de 27.06.2003, grifado nesta citação).

${ }^{161}$ PECES-BARBA, Gregorio (Coord.). Derecho positivo de los derechos humanos. Madrid: Debate, 1987, p. 12.

${ }^{162}$ Ibid., p. 12.

${ }^{163}$ Ibid., pp. 12-13.

${ }^{164}$ CAMARGO, Ricardo Antônio Lucas. Interpretação jurídica e estereótipos. Porto Alegre: Fabris, 2003, p. 13. 
preconceitos antigos ainda está por ser consolidada de fato, e não apenas de direito. A formação de uma consciência social de respeito e convivência saudável com a riqueza de diferenças é vital para a própria identidade política das nações, porquanto, nas palavras de Jürgen Habermas, "a coexistência de formas de vida com direitos iguais significa garantir a cada cidadão a oportunidade de crescer dentro do mundo de uma herança cultural, e garantir aos seus filhos crescerem nele sem sofrerem discriminação”, ${ }^{165}$ porque:

“A integração política dos cidadãos assegura lealdade à cultura política comum. A última tem a sua origem numa interpretação dos princípios constitucionais a partir da perspectiva da experiência histórica da nação. Nesta medida, essa interpretação não pode ser eticamente neutral. Talvez fosse melhor falarmos de um horizonte de interpretação comum dentro do qual os assuntos correntes dão origem a debates sobre o auto-entendimento político dos cidadãos. ${ }^{166 ”}$

\section{A REGRA DE JUSTIÇA E A IMPARCIALIDADE: ISONOMIA E} PODER JUDICIÁRIO

Na reflexão de Norberto Bobbio, identifica-se com precisão que a regra de justiça, quando existem "normas gerais e abstratas que estabeleçam como deve ser tratada toda uma categoria de sujeitos”, ${ }^{167}$ faz com que tal manifestação da justiça formal exija “a virtude da imparcialidade em face dos destinatários da lei, ou seja, exige mais o princípio de legalidade do que a lealdade em face do legislador”. ${ }^{168}$ Assim, o valor da justiça formal está, por definição, "subordinado ao valor instaurado pela justiça retributiva e atributiva”, ${ }^{169}$ eis que, como já referido anteriormente, "pressupõe que já tenham sido escolhidos os critérios para estabelecer quando duas coisas devem ser consideradas equivalentes e quando duas pessoas devem ser consideradas equiparáveis”, ${ }^{170}$ especialmente tendo presente que:

“Quando existem normas desse tipo (e a maioria das leis formais são assim), o respeito à regra de justiça, isto é, à justiça formal, resume-se pura e simplesmente à aplicação escrupulosa e imparcial da lei: com efeito, aplicando-se escrupulosa e imparcialmente uma lei a todos os sujeitos que fazem parte da categoria regulada pela lei e segundo o tratamento previsto, observa-se também a regra da justiça que determina que os iguais sejam tratados de modo igual. ${ }^{171}$,"

Aqui novamente toma relevo a reflexão de Otfried Höffe quando observa que a

\footnotetext{
${ }^{165}$ HABERMAS, Jürgen. Lutas pelo reconhecimento no Estado Democrático Constitucional. In: TAYLOR, Charles. Multiculturalismo: examinando a política de reconhecimento. Lisboa: Instituto Piaget, 1994, pp. 125-164.

${ }^{166}$ Ibid., p. 151.

${ }^{167}$ BOBBIO, 1997a, p. 22.

168 Ibid.

169 Ibid.

${ }^{170}$ BOBBIO, 1997a, p. 20. Norberto Bobbio ainda observa que: “Mesmo tendo um valor subordinado ao valor instaurado pela justiça retributiva e atributiva, também a justiça formal tem por si mesma, ou seja, independentemente do valor de justiça da norma, e mesmo no caso de norma injusta, um valor social, que é o de garantir a velha ordem até que esta seja substituída pela nova.” (Id. Ibid., p. 22).

${ }^{171}$ Ibid., p. 22.
} 
justiça exige "uma condição mínima de imparcialidade", ${ }^{172}$ a qual designa por "proibição de arbítrio", ${ }^{173}$ visto que:

“A imparcialidade também se expressa na exigência de dirimir casos de conflito, 'sem consideração de pessoas', considerando-se como evidente que iustitia não é fortuna, que de sua cornucópia divide e reparte os dons, também sem consideração de pessoa, mas sem escolha. ${ }^{174,}$

E é nesse sentido que Juarez Freitas lembra que o "princípio da imparcialidade»"175 é corolário do "princípio geral da igualdade", ${ }^{176}$ no que cumpre invocar mais uma vez a obra de Bandeira de Mello, na qual, com acuidade, no seu já referido Conteúdo jurídico do princípio da igualdade, o doutrinador paulista identifica a ocorrência de "ofensa ao preceito constitucional da isonomia quando": ${ }^{177}$

"I. A norma singulariza atual e definitivamente um destinatário determinado, ao invés de abranger uma categoria de pessoas, ou uma pessoa futura e indeterminada.

II. A norma adota como critério discriminador, para fins de diferenciação de regimes, elemento não residente nos fatos, situações ou pessoas por tal modo desequiparadas. É o que ocorre quando pretende tomar o fator “tempo" - que não descansa no objeto - como critério diferencial.

III. A norma atribui tratamentos jurídicos diferentes em atenção a fator de discrímen adotado que, entretanto, não guarda relação de pertinência lógica com a disparidade de regimes outorgados.

IV. A norma supõe relação de pertinência lógica existente em abstrato, mas o discrímen estabelecido conduz a efeitos contrapostos ou de qualquer modo dissonantes dos interesses prestigiados constitucionalmente.

V. A interpretação da norma extrai dela distinções, discrimens, desequiparações que não foram professadamente assumidos por ela de modo claro, ainda que por via implícita. ${ }^{178,}$

É, portanto, ainda que com brevidade, importante identificar a tarefa contínua da jurisprudência na garantia de uma igualdade substantiva, pois em nenhuma outra atividade estatal se revela tão intensamente a força normativa do princípio da isonomia e a imanência deste com o todo coerente da ordem constitucional e com a própria idéia de justiça na realidade concreta. Neste aspecto é de referir-se a pertinência da orientação do Supremo Tribunal Federal no tocante ao sentido substancial do disposto no art. 188 do Código de Processo Civil e especialmente no que diz respeito às partes representadas em juízo pela Defensoria Pública, pois a Suprema Corte brasileira acertadamente entendeu que neste particular há uma verdadeira lei ainda constitucional, sendo representativa a seguinte síntese de Gilmar Mendes:

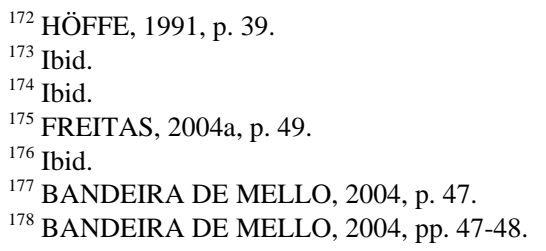


“Inspirado, certamente, na doutrina e na jurisprudência tedescas, em decisão de 23.03.1994, teve o Supremo Tribunal Federal oportunidade de ampliar a já complexa tessitura das técnicas de decisão no controle de constitucionalidade, admitindo que lei que concedia prazo em dobro para a Defensoria Pública era de ser considerada constitucional enquanto esses órgãos não estivessem devidamente habilitados ou estruturados.

Assim, o Relator, Ministro Sydney Sanches, ressaltou que a inconstitucionalidade do $\S 5^{\circ}$ do art. $1^{\circ}$ da Lei $n^{\circ} 7.871$, de 8.11.1989, não haveria de ser reconhecida, no ponto em que confere prazo em dobro, para recurso, às Defensorias Públicas, "ao menos até que sua organização, nos Estados, alcance o nível da organização do respectivo Ministério Público”. ${ }^{179,}$

A importância do Poder Judiciário na preservação da integridade do "princípio dos princípios” também esteve presente na atuação do Supremo Tribunal Federal no período da ditadura militar, quando este estendeu os efeitos de habeas corpus para quem se encontrava na mesma situação jurídica, dado que em memorável atuação de Heleno Fragoso perante a Suprema Corte, ainda no ano de 1966, foi atestado pelo Relator do feito, Ministro Gonçalves de Oliveira:

EMENTA: HABEAS CORPUS - PROFESSORES ACUSADOS DE PRÁTICA DA DOUTRINA COMUNISTA - ORDEM CONCEDIDA [...] - Estou em que os mesmos motivos que determinaram a exclusão da ação penal dos acusados a que me referi - Florestan Fernandes e Fernando Henrique Cardoso - subsistem para Mário Schenberg, João Cruz Costa e Fuad Daher Saad, e, nesta convicção é que concedo a ordem. ${ }^{180}$

No mesmo sentido há significativos julgados que revelam uma dimensão quase que instintiva na atuação dos juristas pátrios diante da eficácia substantiva do princípio constitucional da isonomia, nos quais o Supremo Tribunal Federal, o Superior Tribunal de Justiça e os Tribunais Regionais Federais assentaram que:

O princípio da isonomia, que se reveste de auto-aplicabilidade, não é enquanto postulado fundamental de nossa ordem político-jurídica - suscetível de regulamentação ou de complementação normativa. Esse princípio - cuja observância

\footnotetext{
${ }^{179}$ MENDES, Gilmar Ferreira. Moreira Alves e o controle de constitucionalidade no Brasil. São Paulo: Celso Bastos: Instituto Brasileiro de Direito Constitucional, 2000, p. 63. O feito em tela é o HC 70.514 (julgado em 23.03.1994), $D J$ de 27.06.1997, sendo que o mesmo autor identifica no Recurso Extraordinário Criminal n. 147.776, da relatoria do Ministro Sepúlveda Pertence, a importância da decisão também em face da situação ainda constitucional diante da legitimação do Ministério Público no patrocínio de ressarcimento por dano decorrente de ato criminoso, o que pode ser evidenciado neste excerto da ementa: "Ministério Público: Legitimação para promoção, no juízo cível, do ressarcimento do dano resultante de crime, pobre o titular do direito à reparação: CPP, art. 68, ainda constitucional (cf. RE 135.328): processo de inconstitucionalidade das leis. 1. A alternativa radical da jurisdição constitucional ortodoxa entre a constitucionalidade plena e a declaração de inconstitucionalidade ou revogação por inconstitucionalidade da lei com fulminante eficácia ex tunc faz abstração da evidência de que a implementação de uma nova ordem constitucional não é um fato instantâneo, mas um processo, no qual a possibilidade de realização da norma da constituição - ainda quanto teoricamente não se cuide de preceito de eficácia limitada - subordina-se muitas vezes a alterações da realidade factica que a viabilizem.”

${ }^{180}$ BRASIL. Supremo Tribunal Federal. HC 43.829/GB - GUANABARA. DJ 27.06.1967
} 
vincula, incondicionalmente, todas as manifestações do Poder Público - deve ser considerado, em sua precípua função de obstar discriminações e de extinguir privilégios (RDA 55/114), sob duplo aspecto: (a) o da igualdade na lei e (b) o da igualdade perante a lei. A igualdade na lei - que opera numa fase de generalidade puramente abstrata - constitui exigência destinada ao legislador que, no processo de sua formação, nela não poderá incluir fatores de discriminação, responsáveis pela ruptura da ordem isonômica. A igualdade perante a lei, contudo, pressupondo lei já elaborada, traduz imposição destinada aos demais poderes estatais, que, na aplicação da norma legal, não poderão subordiná-la a critérios que ensejem tratamento seletivo ou discriminatório. A eventual inobservância desse postulado pelo legislador imporá ao ato estatal por ele elaborado e produzido a eiva de inconstitucionalidade. ${ }^{181}$

ADMINISTRATIVO - CONCURSO PÚBLICO - CRITÉRIOS DE FIXAÇÃO DE NOTAS PARA APROVAÇÃO - I - Na fase em que reprovada a recorrente - a prova oral, outros cinco candidatos também não lograram êxito e, assim como ela, buscaram, administrativamente, via recurso, o arredondamento das suas notas, o que possibilitaria a aprovação no certame. Todos, com exceção da recorrente, tiveram acolhida a sua irresignação. II - Demonstração, inequívoca e calcada em dados objetivos constantes nos autos, de que ilegal o "traço desigualador acolhido", in casu, pela Administração. III - Inexistência, sob qualquer aspecto que se aborde, de justificativa objetiva, racional ou plausível para o tratamento jurídico diversificado que se realizou. ${ }^{182}$

$\mathrm{O}$ princípio da isonomia consiste em garantir igualdade de tratamento àqueles que se encontram em situação equivalente. ${ }^{183}$

Por certo que tão injurídico é o deferir-se tratamento idêntico àqueles que em situação desigual se acham quanto tratar-se desigual aqueles que em idênticas condições se encontrem. $^{184}$

\section{A VEDAÇÃO DO ARBÍTRIO}

Quando Francesco Carnelutti disse, ainda em 1943, que "giustizia e certezza sono la medesima cosa”, ${ }^{185}$ não fez mais do que apontar os limites da lei, porque "dipingere un ritratto o costruire un articolo di legge è la stessa cosa", ${ }^{186}$ dado que "si tratta sempre di tradurre nel finito l’infinito", ${ }^{187}$ de tal modo que, inspirado em Vittorio

\footnotetext{
${ }^{181}$ BRASIL. Supremo Tribunal Federal. Mandado de Injunção 58. Relator: Min. Celso de Mello. RTJ 134:1025). 182 BRASIL. Superior Tribunal de Justiça. ROMS - RECURSO ORDINÁRIO EM MANDADO DE SEGURANÇA - 11999. Relator: Min. Feliz Fischer. DJU 23.04.2001.

${ }^{183}$ TRIBUNAL REGIONAL FEDERAL 1ª R. AMS 199001061192. Juiz Antônio Sávio. DJU-II - 13.05.1999.

${ }^{184}$ TRIBUNAL REGIONAL FEDERAL 2a R. Agravo de instrumento 9502090055. Relatora: Juíza Julieta Lídia Lunz. DJU-II - 22.06.1995.

${ }^{185}$ CARNELUTTI, Francesco. La certezza del diritto. In: OÑATE, Flavio Lopez de. La certezza del diritto. Milano: Giuffré, 1968, pp. 199-200 (“justiça e certeza são a mesma coisa.”).

${ }^{186}$ Ibid., pp. 199-200 ("pintar um retrato ou construir um artigo de lei é a mesma coisa.”).

${ }^{187}$ Ibid., pp. 199-200 ("se trata sempre de traduzir no finito o infinito."). O doutrinador italiano ainda observa que (Id. Ibid., pp. 199-200): “La formula d’una legge consiste nella construzione del concetto dei due fatti, tra i quali la successione costante è stata osservata; codesti concetti non sono che dei modelli, i quali servono per il giudizio come una pietra di paragone; se confrontato com il primo termine della
} 
Scialoja, identifica o direito como uma arte, pois a busca da concretização das normas através da hermenêutica identifica a justiça e a certeza com a igualdade.

É, portanto, inegável que o exercício da arte do direito pode contribuir decisivamente para superar ou ao menos mitigar essa realidade quando enfrenta o desafio de buscar a estabilidade democrática, pois, como sempre, com precisão, Norberto Bobbio lembra: “a primeira tarefa de quem pretenda fazer obra de justiça consiste em estabelecer como um determinado indivíduo deve ser tratado para ser tratado de modo justo”. ${ }^{188}$ E na presente reflexão este indivíduo se identifica plenamente com a cidadania brasileira, titular única e em igualdade plena de direitos e obrigações, do direito de definir os desígnios da nação, o que, nas palavras de Pietro Costa acerca do papel seminal de Aristóteles no entendimento do que significa cidadania, resta claro quando se verifica que:

"La partecipazione dei cittadini alla vita della città è strettamente egualitaria: la città è una comunità di eguali che ha come scopo la virtù e l'esercizio di una 'vita buona' e la misura dell'eguaglianza è data dall'alternanza nei ruoli, dalla disponibilità di ciascuno a comandare e a obbedire volta a volta. ${ }^{189,}$

A ordem democrática e republicana, conquistada com o empenho e o sacrifício de várias gerações, é garantidora do Estado Democrático de Direito e valoriza a tarefa

legge, un fatto vi si dimostra conforme, si sa che un altro fatto conforme al secondo termine deve avvenire. In questo dover avvenire sta del secondo fatto la giustizia e, insieme, la certezza; che avvenga è giusto perché è certo e certo perché è giusto; insomma giustizia e certezza sono la medesima cosa. La qual giustizia e certezza si traducono nell'eguaglianza, direi, di tutte le coppie d'un fatto con l'altro perché, come ho cercato di chiarire, più forse che agli altri a me medesimo, la legge tende 'a propagarsi all'infinito' $\mathrm{e}$ così consta 'di una serie o concatenazione infinita di rapporti' (“A fórmula de uma lei consiste na construção do conceito de dois fatos, entre os quais a sucessão constante foi observada; esses conceitos não são nada além de modelos, os quais servem para o juízo como um termo de comparação; se confrontado com o primeiro termo da lei, um fato se demonstra conforme e se sabe que um outro fato deve se conformar ao segundo termo. Neste “dever ser” está, decorrente do segundo fato, a Justiça e, juntamente, a certeza; o que sucede é justo porque é certo e é certo porque é justo; em síntese Justiça e certeza são a mesma coisa. A qual Justiça e certeza se traduzem na igualdade, diria, de todos os pares de um fato com outro porque, como tentei esclarecer, mais talvez aos outros do que a mim mesmo, a lei tende 'a propagarse ao infinito' e deste modo consta ‘de uma série ou concatenação infinita de relações’.”). Ibid., p. 204-205: "Quando io parlai, commemorando Vittorio Scialoja, di arte del diritto, avevo piuttosto intravveduto che veduto che cosa con il diritto l'arte abbia da fare. Pian piano, osservando e meditando, anche intorno a questo un poco la bruma s'è dileguata. Un passo decisivo è stato, nella storia del mio pensiero, aver chiarito il valore della poesia, ch'è ogni guisa di rappresentazione concettuale della realtà. Già, il legislatore ha da essere un poeta. Il problema, la difficoltà, il método non è che questo. Dipingere un ritratto o costruire un articolo di legge è la stessa cosa: si tratta sempre di tradurre nel finito l'infinito" ("Quando eu falei, celebrando Vittorio Scialoja, sobre a arte do direito, tinha mais entrevisto do que visto o que a arte tinha a ver com o direito. Vagarosamente observando e meditando sobre isto a bruma se desfaz um pouco. Um passo decisivo se deu, na história do meu pensamento, quando compreendi o valor da poesia, que é o modo de toda 'representação conceitual da realidade'. Assim, o legislador havia de ser um poeta. O problema, a dificuldade, o método não é senão este. Pintar um retrato ou construir um artigo de lei é a mesma coisa: se trata sempre de traduzir no finito o infinito.”).

${ }^{188}$ BOBBIO, 1997a, p. 21.

${ }^{189}$ COSTA, Pietro. Cittadinanza. Roma-Bari: Laterza, 2005, p. 9 (“A participação dos cidadãos na vida da cidade é estritamente igualitária: a cidade é uma comunidade de iguais que tem como fim a virtude e o exercício de uma 'vida boa' e a medida da igualdade é dada pela alternância nos papéis, pela disponibilidade de cada um de comandar e obedecer a cada vez.”). 
do profissional do direito. Assim, a advertência de Ricardo Camargo, na já referida obra Interpretação jurídica e estereótipos, acerca do "isolamento em que o jurista resolveu se encastelar”, ${ }^{190}$ merece destaque. Não raramente o profissional do direito ignora que os enunciados normativos desconectados da realidade carecem de sentido, porquanto falam em direito e justiça abstraindo que todo fato é "passível de verificação empírica e que, por vezes, esta verificação exige o concurso dos conhecimentos vinculados a outras ciências”, ${ }^{191}$ de tal modo que com acerto o mesmo Ricardo Camargo pondera que:

"Se, por um lado, o in claris cessat interpretatio está praticamente banido como regra de hermenêutica, por outro, a crise de valores que se abateu sobre a humanidade no final do século XX, sobre a qual muita tinta e muitos kb já foram gastos, muitas vezes conduz o intérprete a se alçar à condição de legislador e a introduzir a sua própria tábua de valores ao invés daqueles que foram placitados no produto da vontade geral. ${ }^{192,}$

A tarefa de assegurar a pluralidade democrática e o equilíbrio entre as diversas correntes de opinião e segmentos sociais vai muito além de procedimentos formais e de suas garantias de mesma natureza, visto que reside na igualdade substantiva a possibilidade de uma sociedade melhor e de um Estado que tome distância de caprichos arbitrários e atenda aos reclamos sociais prescritos na própria Constituição Federal, imprescindíveis para que esta cumpra sua função de coesão e integração política da nação. Nas palavras de Bandeira de Mello, "não basta a existência de pressupostos fáticos diversos para que a lei distinga situações sem ofensa à isonomia”,193 ou mesmo o simples invocar de um fundamento racional, dado que "não é qualquer fundamento lógico que autoriza desequiparar, mas tão-só aquele que se orienta na linha de interesse prestigiado na ordenação jurídica máxima”. ${ }^{194}$ É, contudo, importante ter sempre presente o paradigmático magistério de Carmen Lúcia Rocha, dado que com felicidade identifica um autêntico "valor supraconstitucional da igualdade, pois ela se impõe ao próprio ordenamento, mesmo quando não se ache nele expressa". ${ }^{195}$

A idéia de igualdade, portanto, reside sobremaneira na vedação do arbítrio assentada na ordem constitucional e a concretização de tal princípio, na lição de Francesco Carnelutti, ${ }^{196}$ é tarefa do hermeneuta que necessariamente passa pela afirmação conjunta da certeza dos valores jurídicos e da justiça em cada circunstância da vida de uma dada sociedade.

\section{REFERÊNCIAS}

ALEXY, Robert. Teoria de los derechos fundamentales. Traducción de Ernesto Garzón Valdés. Madrid: Centro de Estudios Constitucionales, 1997.

ARISTÓTELES. A Política. Tradução de Nestor Silveira Chaves. Bauru, SP: Edipro, 1995.

${ }^{190}$ CAMARGO, 2003, p. 70.

${ }^{191}$ CAMARGO, 2003, p. 70.

192 Ibid., p. 17.

${ }^{193}$ BANDEIRA DE MELLO, 2004, p. 43.

194 Ibid.

${ }^{195}$ ROCHA, Carmen Lúcia Antunes. Cidadania e Constituição: as cores da revolução do cidadão. Revista Trimestral de Direito Público, nº 19, pp. 19-37, 1997, p. 28.

${ }^{196}$ CARNELUTTI, 1968, pp. 199-200. 
ÁVILA, Humberto. Teoria dos Princípios: da definição à aplicação dos princípios jurídicos. 3. ed. São Paulo: Malheiros, 2004.

BANDEIRA DE MELLO, Celso Antônio. Conteúdo Jurídico do Princípio da Igualdade. 3. ed. São Paulo: Malheiros, 2004.

Curso de Direito Administrativo. 19. ed. São Paulo: Malheiros, 2005.

BARBOSA GOMES, Joaquim B. Ação afirmativa \& princípio constitucional da igualdade: o direito como instrumento de transformação social. A experiência dos EUA. São Paulo: Renovar, 2001.

BASTOS, Celso Ribeiro; MARTINS, Ives Gandra. Comentários à Constituição do Brasil: promulgada em 5 de outubro de 1988. São Paulo: Saraiva, 1989.

BERLIN, Isaiah. Estudos sobre a humanidade: uma antologia de ensaios. Tradução de Rosaura Eichenberg. São Paulo: Companhia das Letras, 2002.

BOBBIO, Norberto. Igualdade e Liberdade. Tradução de Carlos Nelson Coutinho. 2. ed. Rio de Janeiro: Ediouro, 1997.

BONAVIDES, Paulo; ANDRADE, Paes de. História Constitucional do Brasil. 3. ed. Rio de Janeiro: Paz e Terra, 1991.

BORGES, José Souto Maior. Princípio da isonomia e sua significação na Constituição de 1988. Revista de Direito Público, São Paulo, v. 23, n. 93, jan.-mar. 1990.

CALMON DE PASSOS, J. J. O princípio de não discriminação. Jus Navigandi, no 57 (07.2002). Disponível em: http://www1.jus.com.br/doutrina/texto.asp?id=2990. Acesso em: 25 nov. 2004. CAMARGO, Ricardo Antônio Lucas. Interpretação Jurídica e Estereótipos. Porto Alegre: Fabris, 2003.

CARBONELL, Miguel. La igualdad y los derechos humanos. In: CARBONELL, Miguel. (Comp.). El principio constitucional de igualdad: lecturas de introducción. México: Comisión Nacional de los Derechos Humanos, 2003.

ROCHA, Carmen Lúcia Antunes. Cidadania e Constituição: as cores da revolução do cidadão. Revista Trimestral de Direito Público, no 19, pp. 19-37, 1997.

CARNELUTTI, Francesco. La certezza del diritto. In: OÑATE, Flavio Lopez de. La certezza del diritto. Milano: Giuffré, 1968.

COSTA, Pietro. Cittadinanza. Roma-Bari: Laterza, 2005.

DEL VECHIO, Giorgio. Lições de Filosofia do Direito. Tradução de António José Brandão. 5. ed. Coimbra: Armênio Amado, 1979.

DWORKIN, Ronald. A virtude soberana: a teoria e a prática da igualdade. Tradução de Jussara Simões. São Paulo: Martins Fontes, 2005

FREITAS, Juarez. O controle dos atos administrativos e os princípios fundamentais. 3. ed. São Paulo: Malheiros, 2004.

GARCÍA, Eusebio Fernández. Entre la razón de Estado y el Estado de Derecho: la racionalidad política. Madrid: Dykinson, 1997.

GRAU, Eros Roberto. A Ordem Econômica na Constituição de 1988: interpretação e crítica. São Paulo: Revista dos Tribunais, 1990.

HABERMAS, Jürgen. Lutas pelo reconhecimento no Estado Democrático Constitucional. In: TAYLOR, Charles. Multiculturalismo: examinando a política de reconhecimento. Lisboa: Instituto Piaget, 1994, pp. 125-164. 
HANSEN, João Adolfo. Razão de Estado. NOVAES, Adauto (Org.). A crise da razão. São Paulo: Companhia das Letras; Brasília, DF: Ministério da Cultura; Rio de Janeiro: Fundação Nacional de Arte, 1996.

HÖFFE, Otfried. Justiça Política. Tradução: Ernildo Stein. Petrópolis: Vozes, 1991.

JACQUES, Paulino. Da igualdade perante a lei: fundamento, conceito e conteúdo. Rio de Janeiro: Forense, 1957.

LIMONGI, Dante Braz. O Projeto Político de Pontes de Miranda: Estado e democracia na obra de Pontes de Miranda. Rio de Janeiro: Renovar, 1998.

MENDES, Gilmar Ferreira. Moreira Alves e o Controle de Constitucionalidade no Brasil. São Paulo: Celso Bastos: Instituto Brasileiro de Direito Constitucional, 2000.

MIGUEL, Alfonso Ruiz. Sobre el concepto de igualdad. In: CARBONELL, Miguel. (Comp.). El principio constitucional de igualdad: lecturas de introducción. México: Comisión Nacional de los Derechos Humanos, 2003.

MIRANDA, Jorge. Manual de Direito Constitucional. 3. ed. Coimbra: Coimbra, 2000, v. 4.

NUNES, António José Avelãs. Neoliberalismo e Direitos Humanos. Rio de Janeiro: Renovar, 2003. PECES-BARBA, Gregorio (Coord.). Derecho positivo de los derechos humanos. Madrid: Debate, 1987.

PONTES DE MIRANDA, Francisco Cavalcanti. Comentários à Constituição de 1946. 4. ed. Rio de Janeiro: Editor Borsoi, 1963, t. IV.

. Comentários à Constituição de 1967/69. 3. ed. Rio de Janeiro: Forense, 1987, t. IV. Democracia, liberdade, igualdade: os três caminhos. 2. ed. São Paulo: Saraiva, 1979. Sistema de ciência positiva do direito. 2. ed. Rio de Janeiro: Borsoi, 1972, t. I.

PORTO, Sérgio Gilberto. Cidadania processual e relativização da coisa julgada. Revista Jurídica, v. 51, no 304, pp. 23-31, fev. 2003.

REALE, Miguel. Filosofia do Direito. 9. ed. São Paulo: Saraiva, 1982.

ROUANET, Sergio Paulo. Mal-estar na modernidade: ensaios. São Paulo: Companhia das Letras, 1993.

SARLET, Ingo Wolfgang. Dignidade da Pessoa Humana e Direitos Fundamentais na Constituição Federal de 1988. 5. ed. Porto Alegre: Livraria do Advogado, 2007.

SILVA, José Afonso da. Curso de Direito Constitucional Positivo. 13. ed. São Paulo: Malheiros, 1997.

PERIÓDICOS E OUTROS

CONSTITUIÇÃO da República Federativa do Brasil

BRASIL. Supremo Tribunal Federal. HC 43.829/GB - GUANABARA. DJ 27.06.1967

BRASIL. Supremo Tribunal Federal. Mandado de Injunção 58. Relator Min. Celso de Mello. RTJ 134:1025).

BRASIL. Superior Tribunal de Justiça. ROMS - RECURSO ORDINÁRIO EM MANDADO DE SEGURANÇA - 11999. Relator Min. Feliz Fischer. DJU 23.04.2001.

TRIBUNAL REGIONAL FEDERAL 1ª R. AMS 199001061192. Juiz Antônio Sávio. DJU-II - 13.05.1999.

TRIBUNAL REGIONAL FEDERAL 2 ${ }^{\text {a }}$ R. AI 9502090055. Relatora Juíza Julieta Lídia Lunz. DJU-II - 22.06.1995. 